\title{
Climate and geology overwrite land use effects on soil organic nitrogen cycling on a continental scale
}

\author{
Lisa Noll ${ }^{1,2}$, Shasha Zhang ${ }^{1}$, Qing Zheng ${ }^{1}$, Yuntao $\mathrm{Hu}^{1,3}$, Florian Hofhansl ${ }^{4}$ and Wolfgang Wanek ${ }^{{ }^{*}}$ \\ ${ }^{1}$ Division of Terrestrial Ecosystem Research, Department of Microbiology and Ecosystem Science, Center of Microbiology \\ 5 and Environmental Systems Science, University of Vienna, Vienna, Austria \\ ${ }^{2}$ German Environment Agency, Dessau-Rosslau, Germany \\ ${ }^{3}$ Lawrence Berkeley National Laboratory, Berkeley, USA \\ ${ }^{4}$ International Institute for Applied Systems Analysis, Schlossplatz 1, A-2361 Laxenburg, Austria
}

Correspondence to: Wolfgang Wanek (wolfgang.wanek@univie.ac.at)

10 Abstract. Soil fertility and plant productivity are globally constrained by $\mathrm{N}$ availability. Proteins are the largest $\mathrm{N}$ reservoir in soils and the cleavage of proteins into small peptides and amino acids has been shown to be the rate limiting step in the terrestrial $\mathrm{N}$ cycle. However, we are still lacking a profound understanding of the environmental controls of this process. Here we show that integrated effects of climate and soil geochemistry drive protein cleavage across large scales. We measured gross protein depolymerization rates in mineral and organic soils sampled across a 4000-km-long European

15 transect covering a wide range of climates, geologies and land uses. Based on structural equation models we identified that soil organic $\mathrm{N}$ cycling was strongly controlled by substrate availability e.g. by soil protein content. Soil geochemistry was a secondary predictor by controlling protein stabilization mechanisms and protein availability. Precipitation was identified as the main climatic control on protein depolymerization by affecting soil weathering and soil organic matter accumulation. In contrast, land use was a poor predictor of protein depolymerization. Our results highlight the need to consider geology and precipitation effects on soil geochemistry when estimating and predicting soil $\mathrm{N}$ cycling at large scales.

\section{Introduction}

Microbial decomposition of soil organic matter is a fundamental driver of soil ecosystem functions and services e.g. nutrient regeneration through decomposition maintains soil fertility and plant productivity. For example, the extracellular cleavage of plant- and microbial-derived soil proteins, chitin or peptidoglycan to small organic compounds such as peptides, amino acids and amino sugars regulates organic $\mathrm{N}$ uptake by soil microbes, contributes to plant $\mathrm{N}$ nutrition and further drives terrestrial inorganic N cycling (Hu et al., 2018; Noll et al., 2019b). Proteins account for up to $90 \%$ of soil N (Martens and Loeffelmann, 2003; Schulten and Schnitzer, 1997). Protein depolymerization is mediated by extracellular enzymes and facilitates microbes and plants to utilize the by far single largest $\mathrm{N}$ reservoir in soils. However, the large-scale controls of gross protein depolymerization are largely unknown. Since protein depolymerization is mediated by extracellular enzymes it is tied to substrate availability, soil geochemistry and microbial N demands driving enzyme production (Sinsabaugh et al., 
https://doi.org/10.5194/bg-2022-41

Preprint. Discussion started: 22 February 2022

(c) Author(s) 2022. CC BY 4.0 License.

\section{(c) (i)}

2008). Across biogeographic regions peptidase activity increases strongly with soil $\mathrm{pH}$ since the $\mathrm{pH}$ optima of most proteolytic enzymes is about $7-8$ (Sinsabaugh et al., 2008; Hendriksen et al., 2016). Moreover, soil pH is a major control on bacterial community composition and cross-continental studies showed that this pattern is consistent across soil types and biomes (Lauber et al., 2009; Rousk et al., 2010; Fierer and Jackson, 2006). Given the large difference in the excreted enzyme complement between microbial taxa, soil nutrient status and edaphic properties (e.g. soil $\mathrm{pH}$, texture and cation exchange capacity) shape the set of excreted proteolytic enzymes (Lauber et al., 2009; Lauber et al., 2008; Jangid et al., 2008; Fuka et al., 2008) by their effects on microbial community composition. Effects of climate on peptidase activity are rather indirect, indicated by shifts in vegetation type and in soil nutrient stoichiometry from low to high latitudes (Hendriksen et al., 2016; Sinsabaugh et al., 2008; Peng and Wang, 2016). Soil C:N ratios are typically higher in forest soils than in agricultural soils, and affect in particular the fungi: bacteria ratios (Lauber et al., 2008). Land use can consequently affect the production of soil extracellular enzymes (Jangid et al., 2008).

Substrate availability is likely the most striking control on organic $\mathrm{N}$ depolymerization rates and has been shown to be driven by land use and soil properties at the regional scale (Noll et al., 2019b). Soil N stocks as proxy for protein contents are typically increasing with mean annual precipitation and to decrease with the level of aridity (Delgado-Baquerizo et al., 2013; Marty et al., 2017; Callesen et al., 2007). Changes in temperature and precipitation patterns are associated with changes of the potential natural vegetation, where $\mathrm{N}$ becomes progressively limiting with vegetation changes from deciduous to coniferous shrubs and trees and from low to high latitudes (Kang et al., 2010; Reich and Oleksyn, 2004). Moreover, soil N stocks decrease with intensification of land management, from forests to grasslands and croplands (Six and Jastrow, 2002). Decomposition experiments of plant litter and organic soils showed an inverse relationship of gross protein depolymerization

50 rates and resource $\mathrm{C}: \mathrm{N}$ ratios and a positive with $\mathrm{N}$ content, suggesting that protein depolymerization is rather controlled by substrate availability than by the pool size of extracellular enzymes (Mooshammer et al., 2012). However, in mineral soils this relationship was less pronounced, indicating that protein stabilization on mineral surfaces may restrict soil protein cleavage (Wild et al., 2013; Noll et al., 2019b).

In mineral soils, organic nitrogen availability is constrained by interactions of organic compounds with the soil matrix e.g. formation of organo-mineral associations, and restricted accessibility in small pores and soil aggregates render soil organic matter protected from enzymatic attack (Kögel-Knabner et al., 2008; Quiquampoix, 2000). Stabilization mechanisms are controlled by soil texture and soil mineral assemblage, and particularly by the amounts of Fe- and $\mathrm{Al}$ oxyhydroxide which are major sorption sites of soil organic matter in soils (Kaiser and Guggenberger, 2000). Their amount and composition are shaped by soil parent material (primary minerals) and environmental conditions during pedogenesis 60 controlling bedrock weathering and the formation of secondary minerals. Both, protein availability and proteolytic activity are further constrained by the formation of metal-organic complexes or complexation with tannins (Nierop et al., 2002; Peter J Hernes, 2001; Adamczyk et al., 2009).

Land use, bedrock and biogeographic region are therefore key controls on soil nutrient status and edaphic properties and affect microbial community structure, substrate availability and microbial $\mathrm{N}$ and $\mathrm{C}$ demands (Figure 1). Changes in 
environmental conditions might thereby be translated into altered organic $\mathrm{N}$ process rates. To investigate the major controls on organic N cycling, we sampled a large-scale transect across Europe from the Mediterranean to the Subarctic, covering three different land use types (forest/shrub land, grassland and cropland) as well as a wide range of climates and geologies and determined gross protein depolymerization rates using an isotope pool dilution approach targeting soil amino acid production (protein depolymerization).

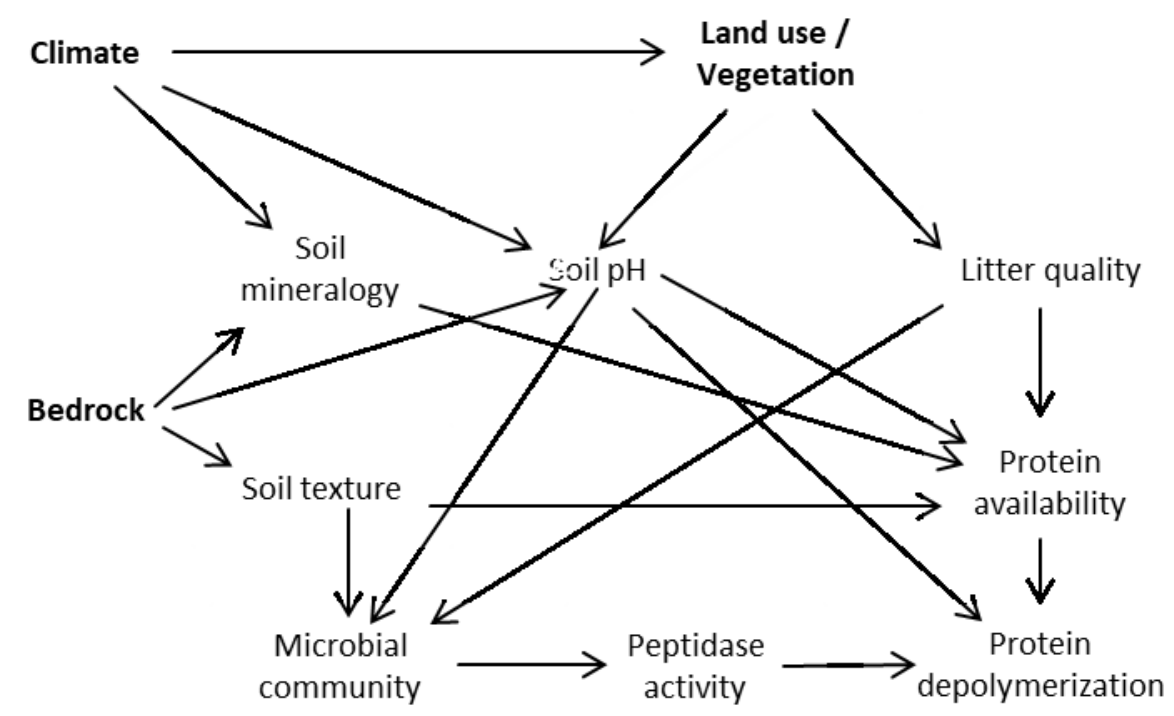

Figure 1 Proposed model relating climate, bedrock and land use effects to protein depolymerization rates.

We hypothesized that (I) protein depolymerization is restricted by the lower soil organic matter content and microbial activity in cropland soils compared to grassland and forest soils. (II) We further expected that the availability of proteins and thereby gross protein depolymerization rates are controlled by soil geochemical properties (e.g. soil $\mathrm{pH}$ ), mineral assemblage and texture. (IV) We further hypothesized that climate is a rather indirect control on organic $\mathrm{N}$ cycling by its effects on vegetation and soil geochemistry as well as on soil $\mathrm{N}$ stocks.

\section{Materials and Methods}

\subsection{Sampling}

Soil samples were collected during summer 2017 (May to August) at the peak of the growing season across a European continental transect from the warm Mediterranean to the cold Subarctic and from the humid Atlantic western climate to the dry continental steppes in Romania (Figure 2). The sampled soils were distinct in soil parent material, soil type, land use and vegetation. Sampling sites were selected to represent the natural vegetation as defined in the 'Map of the natural vegetation of Europe' (Bohn and Katenina, 2000). For each sampling site climate data scaled to $100 \mathrm{~m}$ were extracted from the WorldClim database vs. 1.4 (Fick and Hijmans, 2017). Bedrock was obtained from the international geological map of 
Europe (IGME5000, 1:5.000.000 (Asch, 2005)) and dominant soil types were obtained from the "Soil regions of European Union and adjacent areas" map (EUSR5000, 1:5.000.000, (Bgr [Bundesanstalt Für Geowissenschaften Und Rohstoffe], 2005).

For statistical analyses bedrock types were binned into three groups: limestone, sediment and silicate. Sediment geologies included Flysch, Molasse, till and fluvial sand, silicate bedrock included plutonic, igneous and metamorphic formations, and

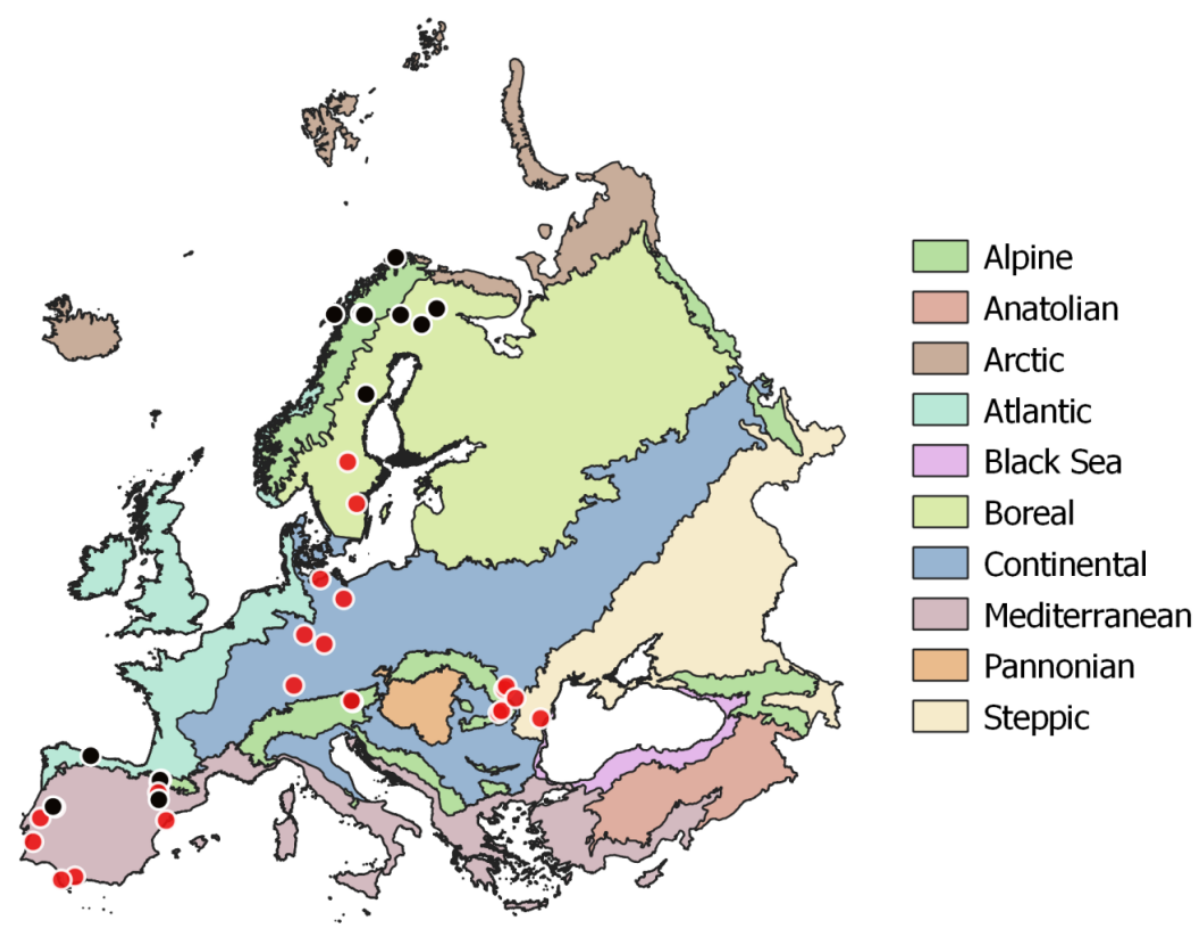

Figure 2 Sampling sites across European biogeographical regions. Red circles symbolize sampling sites including three land use types (woodland, grassland, cropland). Map of European biogeographical regions was obtained from biogeographical regions dataset of the European Environment Agency.

90 carbonate bedrock ranged from dolomite to limestone and marl. Mean annual temperature (MAT) of the sampling sites ranged from -3.5 to $17.8{ }^{\circ} \mathrm{C}$ and mean annual precipitation ranged from 415 to $1396 \mathrm{~mm} \mathrm{y}^{-1}$. Where possible, all three management types (woodland/forest, grassland and cropland) as well as mineral and organic soils were sampled in close vicinity. In the following we only use 'woodland' for subarctic tundra, open woodlands and forests. At each site bulk samples of mineral top soil $(0-15 \mathrm{~cm})$ were taken with a soil corer $(5 \mathrm{~cm})$. Each bulk soil sample consisted of five replicates 95 with about $5 \mathrm{~m}$ distance from each other. In total we sampled 96 mineral top soils from 43 sites. 23 sites included woodland, grassland and cropland soils (Table S1). Organic layers were sampled at 13 sites using a $20 \mathrm{x} 20 \mathrm{~cm}$ frame to cut out the organic horizon down to the mineral soil surface. Representative leaf litter samples were collected at each site and represent 
https://doi.org/10.5194/bg-2022-41

Preprint. Discussion started: 22 February 2022

(c) Author(s) 2022. CC BY 4.0 License.

\section{(c) (i)}

the dominating vegetation. Roots and stones were removed from the soil samples manually immediately after sampling. Soil samples, roots, stones and litter samples were cooled $\left(4-8{ }^{\circ} \mathrm{C}\right)$ and shipped within 3 to 7 days to the University of Vienna for further analyses. Soil samples were homogenized by sieving to $2 \mathrm{~mm}$ and separate aliquots were air dried or stored moist at 4 ${ }^{\circ} \mathrm{C}$. Litter and root samples were washed and dried in a drying oven at $60^{\circ} \mathrm{C}$.

\subsection{Basic soil parameters}

Soil texture, $\mathrm{CaCO}_{3}$ content, cation exchange capacity (CEC), base saturation (BS) and exchangeable $\mathrm{Ca}^{2+} \mathrm{Mg}^{2+}, \mathrm{K}^{+}, \mathrm{Na}^{+}$, $\mathrm{Al}^{3+}, \mathrm{Fe}^{3+}$ and $\mathrm{H}^{+}$were determined by the Austrian Agency for Health and Food Safety (AGES) according to European and international standards (ÖNORM). Fe- and Al-oxyhydroxides were determined in acid ammonium oxalate and in Nadithionite extracts (Loeppert, 1996) at the Institute of Soil Research (IBF, University of Natural Resources and Life Sciences, Vienna, Austria). Oxalate extractable $\mathrm{Fe}\left(\mathrm{Fe}_{\text {oxalate }}\right)$ and $\mathrm{Al}\left(\mathrm{Al}_{\text {oxalate }}\right)$ refers to amorphous $\mathrm{Fe}$ - and $\mathrm{Al}$ oxyhydroxides and Fe bound in organo-metal complexes. Dithionite extractable Fe minus oxalate extractable Fe represents $\mathrm{Fe}$ bound in crystalline oxyhydroxides $\left(\mathrm{Fe}_{\mathrm{d}-\mathrm{o}}\right)$. The ratio of oxalate extractable Fe over dithionite extractable Fe presents a measure of the activity of the Fe-mineral phase $\left(\mathrm{Fe}_{\mathrm{o} / \mathrm{d}}\right)$. To determine the soil water content, sieved soils were dried at $85^{\circ} \mathrm{C}$ for $48 \mathrm{~h}$. Water holding capacity (WHC) was measured by repeatedly saturating $10 \mathrm{~g}$ field-moist soil with deionized water and draining in between for 2.5 hours in a funnel with an ash-free cellulose filter paper. Field-moist soils were either adjusted to $60 \%$ WHC by gentle drying at room temperature or by addition of deionized water. Before further analyses all soils were pre-incubated for two weeks at $20{ }^{\circ} \mathrm{C}$ and $60 \%$ water holding capacity (WHC) in PE-Ziploc bags. Soil pH was measured in water and 10 $\mathrm{mM} \mathrm{CaCl}_{2}(1: 5$ (w : v)) using an ISFET pH sensor (Sentron, Leek, The Netherlands). To determine total C and total $\mathrm{N}$ in root and litter as well as soil organic $\mathrm{C}(\mathrm{SOC})$ and soil total $\mathrm{N}(\mathrm{TN})$ oven dried root, litter and soil samples were ground with a ball mill (MM 200, Retsch, Germany) and analyzed by an Elemental analyzer (Carlo Erba 1110, CE Instruments) coupled to a Delta ${ }^{\text {Plus }}$ Isotope Ratio Mass Spectrometer (Finnigan MAT, Germany) via a Conflo III interface (Thermo Fisher, Austria). If necessary, carbonates were removed from soil samples with $2 \mathrm{M} \mathrm{HCl}$ prior to SOC and TN measurements. Soil total P (TP) and soil total inorganic P (TIP) were determined in $0.5 \mathrm{M} \mathrm{H}_{2} \mathrm{SO}_{4}$ extracts of ignited $\left(450{ }^{\circ} \mathrm{C}, 4{ }^{\circ} \mathrm{C}\right.$ (Lajtha et al., 1999)) and control soil aliquots followed by malachite green measurements of reactive phosphate (Kuo, 1996). Total soil organic P (TOP) was calculated as the difference of TP - TIP. Soils were extracted with $1 \mathrm{M} \mathrm{KCl} \mathrm{(1:5} \mathrm{(w:v))} \mathrm{for} 1 \mathrm{~h}$ and filtered through ash-free cellulose filters (Whatmann). Dissolved organic C (DOC) and total N (TDN) were measured in the extracts by a TOC/TN analyzer (TOC-VCPH/TNM-1, Shimadzu, Austria). $\mathrm{NH}_{4}{ }^{+}$and $\mathrm{NO}_{3}{ }^{-}$were measured colorimetrically in the same extracts (Hood-Nowotny et al., 2010). Dissolved organic N (DON) was calculated as TDN minus $\mathrm{NO}_{3}{ }^{-}$and $\mathrm{NH}_{4}{ }^{+}$. Free amino acids (FAA) were determined fluorimetrically in $1 \mathrm{M} \mathrm{KCl}$ extracts by the OPAME fluorescence method (Jones et al., 2002) as modified by Prommer et al. (2014). Dissolved inorganic P (DIP, Olsen P) was extracted with 0.5 M $\mathrm{NaHCO}_{3}(1: 7.5(\mathrm{w}: \mathrm{v}), \mathrm{pH} 8.5)$ for $1 \mathrm{~h}$, filtered through ash free cellulose filters and measured by malachite green. Total dissolved P (TDP) was measured following acid persulfate digestion and dissolved organic P (DOP) was calculated as the difference of $\mathrm{P}$ concentration between digested and non-digested samples (Lajtha et al., 1999). Soil microbial community 
https://doi.org/10.5194/bg-2022-41

Preprint. Discussion started: 22 February 2022

(c) Author(s) 2022. CC BY 4.0 License.

\section{(c) (i)}

composition was analyzed by phospholipid fatty acid (PLFA) analyses according to Kaiser et al. (2010) and Hu et al. (2018). Microbial C, N and P were determined by chloroform fumigation extraction (Brookes et al., 1985). Sample aliquots were fumigated for $48 \mathrm{~h}$ and subsequently extracted as described above with $1 \mathrm{M} \mathrm{KCl}$ or $0.5 \mathrm{M} \mathrm{NaHCO}_{3}$. Potential activities of leucine-amino peptidase (EC 3.4.11.1) was determined in buffered (Na-acetate, $\mathrm{pH} 5.5$ ) and unbuffered (ultra-pure water)

135 soil slurries using L-leucine-7-amido-4-methyl coumarin (AMC-leucine) as substrate (Kaiser et al., 2010). Triplicates of each sample were incubated for $2 \mathrm{~h}$ at $25{ }^{\circ} \mathrm{C}$ and measured every $30 \mathrm{~min}$. Fluorescence was measured with a TECAN InfiniteR M200 (Austria) spectrophotometer at an excitation wavelength of $365 \mathrm{~nm}$ and an emission wavelength of $450 \mathrm{~nm}$, and was corrected for sample blank fluorescence and quenching prior to calculations of AMC concentration.

\section{3 $\mathrm{NaOH}$ extractable protein}

$1402 \mathrm{~g}$ of fresh soil were extracted with $0.5 \mathrm{M} \mathrm{NaOH}(1: 10(\mathrm{w}: \mathrm{v}))$ for $2 \mathrm{~h}$ in an ultra-sonic bath (160 W, Sonorex RK510, Germany) and subsequently for further $16 \mathrm{~h}$ on a rotary shaker. $\mathrm{NaOH}$ extracts free and loosely bound proteins e.g from organo-mineral associations but not proteins stabilized in metal-organo complexes (Wattel-Koekkoek et al., 2001). Extracts were centrifuged for $15 \mathrm{~min}$ at $1600 \mathrm{x} \mathrm{g}$. As high salt concentrations interfere with the consequent measurement of hydrolyzed amino acids, $2.5 \mathrm{ml}$ of supernatant were desalted using Sephadex ${ }^{\mathrm{TM}}$ G-25 columns (PD10 GE Healthcare,

145 Uppsala, Sweden). For determination of total amino acids we adopted a method published by Martens and Loeffelmann (2003) and $\mathrm{Hu}$ et al. (2018). The purified extracts were freeze-dried and re-dissolved in $1.5 \mathrm{ml}$ methanesulfonic acid (4 M MSA). $1 \mathrm{ml}$ of samples, bovine serum albumin (BSA) standards, and blanks were hydrolyzed in an autoclave for $1 \mathrm{~h}$ at 135 ${ }^{\circ} \mathrm{C}$. Hydrolyzed extracts were neutralized with $4 \mathrm{M} \mathrm{KOH}$ and measurements were performed on an HPLC system (Dionex ICS-3000, Thermo Fisher Scientific, Bremen, Germany) coupled to an electrochemical detector. Amino acids were separated using a PA-10 IC column (Thermo Fisher Scientific, Bremen, Germany). NaOH-extractable protein (Protein $\mathrm{NaOH}_{\text {) was }}$ calculated as the sum of the 20 measured amino acids.

\subsection{Gross organic N processes}

One day before starting the pool dilution experiment FAA concentrations were determined in an aliquot of pre-incubated soil. The isotope pool dilution experiment and sample analyses were conducted as described previously by Noll et al.

155 (2019a). In brief, $4 \mathrm{~g}$ of soil were weighed into transparent HDPE vials in duplicates and $400 \mu \mathrm{l}$ of a ${ }^{15} \mathrm{~N}$ tracer solution were added drop wise. Samples were shaken vigorously to guarantee good mixing of the tracer. The tracer solution was prepared from a highly ${ }^{15} \mathrm{~N}$ enriched amino acid mixture (U-15N-98 at $\%{ }^{15} \mathrm{~N}$ amino acid mixture from crude algal protein, Cambridge Isotope Laboratories, Radeberg, Germany). The total amount of added ${ }^{15} \mathrm{~N}$ was adjusted to about $20 \%$ of the native FAA pool. The incubation was terminated after 15 and $45 \mathrm{~min}$ by addition of cold $\mathrm{KCl}\left(4{ }^{\circ} \mathrm{C}\right)$ and samples were extracted for $1 \mathrm{~h}$

160 on a rotary shaker and filtered at $4{ }^{\circ} \mathrm{C}$. Prior to measuring the isotopic composition of $\mathrm{FAA} \mathrm{NH}_{4}^{+}$was removed by microdiffusion Lachouani et al. (2010); (Noll et al., 2019a). Extracts were microdiffused for $48 \mathrm{~h}$. To measure the concentration and atom $\%{ }^{15} \mathrm{~N}$ of FAA $2 \mathrm{ml}$ of pre-treated extracts were transferred into $12 \mathrm{~mL}$ glass exetainers and the $\alpha$ - 
amino group was cleaved/oxidized by $\mathrm{NaClO}$ and $\mathrm{KBr}$ as catalyst under alkaline conditions as described by Zhang and Altabet (2008) and modified by Noll et al. (2019a). Subsequently the produced $\mathrm{NO}_{2}^{-}$was converted to $\mathrm{N}_{2} \mathrm{O}$ by buffered

$165 \mathrm{NaN}_{3}\left(\mathrm{NaN}_{3}\right.$ in $100 \%$ acetic acid 1:1). The produced $\mathrm{N}_{2} \mathrm{O}$ was measured with a purge-and-trap isotope ratio mass spectrometer (PT-IRMS) consisting of a Finnigan Delta V Advantage IRMS (Thermo Fisher, Germany) and a Gasbench II headspace analyzer (Thermo Fisher, Germany) with cryo-focusing unit. Calibration was done according to Lachouani at al. (2010) and Noll et al. (2019a)

\subsection{Data analyses and statistics}

170 Gross rates of protein depolymerization (GP) and microbial amino acid uptake (GU) were calculated according to Kirkham and Bartolomew (1954) and Wanek et al. (2010):

$$
\begin{gathered}
G P=\frac{\left(N_{t 2}-N_{t 1}\right.}{(t 2-t 1)} * \frac{\mathrm{LN}\left[\frac{\left(a t \%{ }^{15} N_{t 1}-a t \%^{15} N_{b}\right)}{\left(a t \%{ }^{15} N_{t 2}-a t \%^{15} N_{b}\right)}\right]}{L N\left(\frac{N_{t 2}}{N_{t 1}}\right)} \\
G U=\frac{\left(N_{t 1}-N_{t 2}\right.}{(t 2-t 1)} *\left(1+\frac{\operatorname{LN}\left[\frac{\left(a t \%{ }^{15} N_{t 2}-a t \%^{15} N_{b}\right)}{\left(a t \%{ }^{15} N_{t 1}-a t \%^{15} N_{b}\right)}\right]}{L N\left(\frac{N_{t 2}}{N_{t 1}}\right)}\right)
\end{gathered}
$$

where $\mathrm{N}_{\mathrm{t} 1}$ and $\mathrm{N}_{\mathrm{t} 2}$ are the concentrations of FAA-N at the time points $\mathrm{t} 1(15 \mathrm{~min})$ and $\mathrm{t} 2(45 \mathrm{~min}) .{ }^{15} \mathrm{~N}$ content in amino acids at the time points of termination are expressed as at $\%{ }^{15} \mathrm{~N}_{\mathrm{t} 1}$ and $\mathrm{at} \%{ }^{15} \mathrm{~N}_{\mathrm{t} 2}$, while at $\%{ }^{15} \mathrm{~N}_{\mathrm{b}}$ is the background ${ }^{15} \mathrm{~N}$ abundance $\left(0.366\right.$ at $\left.\%{ }^{15} \mathrm{~N}\right)$ in non-labeled samples. Mean residence times of FAA were estimated as free amino acid pool size divided by microbial amino acid uptake rate. Microbial C:N and N:P imbalances were calculated as the ratio of resource C:N or N:P over microbial C:N or N:P.

For statistical analyses mineral soils were grouped by bedrock (limestone, sediments, silicates) or by land use (cropland, grassland, woodlands). Prior to statistical analyses data were checked for normality and transformed if necessary. Effects of bedrock were analyzed by one-way analysis of variance (ANOVA) followed by Tukey HSD tests. To analyze land use effects on process rates and soil properties site was included as factor in a two-way ANOVA to account for differences between sites (climate, bedrock, soil type). Land use effects were only analyzed for 22 sites where cropland, grassland and woodland soils could be sampled in close vicinity. Differences in process rates and soil properties between organic and underlying mineral soil horizons were analyzed by paired t-tests for the 13 sites where organic and mineral horizons were sampled. Linear mixed models were used to explore the effect of soil properties and climate on protein depolymerization rates with land use as random factor. The most parsimonious model was selected by Akaike's information criterion (AIC). Multicollinearity was assessed by variance inflation factors (VIF). Variables with VIF larger than 2.5 were excluded from the model. Partial correlations were used to control for the effect of soil geochemical properties on the relationship between 
https://doi.org/10.5194/bg-2022-41

Preprint. Discussion started: 22 February 2022

(c) Author(s) 2022. CC BY 4.0 License.

\section{(c) (i)}

climate and the response variables (i.e. protein depolymerization rates, leucine-amino peptidase activity and $\mathrm{NaOH}-$ extractable Protein; (Doetterl et al., 2015; Luo et al., 201). Significant changes of the correlation coefficient were assumed when the $95 \%$ confidence interval of the zero-order correlation and the partial correlation did not overlap. Partial correlations were analyzed using 'ppcor' in R environment (Kim, 2015). Effects of climate parameters and their interactions on process rates were assessed by linear mixed effect models with soil parent material or land use as random effects. We used structural equation modelling (SEM) to explore direct and indirect effects of climate, geology and soil properties on protein depolymerization rates. We used parameters which correlated significantly with protein depolymerization to construct a base model for gross protein depolymerization rates. Input variables were tested for multivariate normality and linearity. If necessary variables were log transformed to mitigate departure from model assumptions. The model was then analyzed using the 'lavaan' package (Rosseel, 2018) in R. Model fit was evaluated using Chi-square statistics ( $>0.05$ ). The most parsimonious model was identified by step-wise deletion of non-significant paths. Akaike's information criterion (AIC) was used to compare competing model fits. We followed the two-index strategy proposed by Hu and Bentler (1999) to describe the specified model and the data covariance-matrix and reported root mean square error of approximation (RMSEA) and standardized root mean square residual (SRMR). Good model-data fit is indicated by RMSEA $\leq 0.06$ and SRMR $\leq$ 0.08. All statistics were performed in R 3.1.3 (R Development Core Team, 2008).

\section{Results}

\subsection{Effects of bedrock, land use, soil horizon and climate}

Soil properties, leucine-amino peptidase activity, gross protein depolymerization, FAA uptake and MRT of FAA were analyzed for differences between mineral soils of the three major bedrock classes (limestones, sediments and silicates) and land use types (cropland, grassland, woodland), as well as for differences between the two soil horizons (mineral, organic, Table S2). Bedrock had significant effects on soil physicochemical properties but not on root biomass, root C: $\mathrm{N}_{\text {and }} \mathrm{NO}_{3}{ }^{-}$.

210 Soil $\mathrm{pH}$ measured in water was highest in limestone soils (7.9 \pm 1.1$)$ followed by sediment soils $(6.0 \pm 1.1)$ and silicate soils (5.3 \pm 0.9$)$. Clay content increased in the order silicate $<$ sediment $<$ limestone. Limestone soils were characterized by higher $\mathrm{Fe}_{\mathrm{d}-\mathrm{o}}$, representing crystalline Fe oxides, $\left(13.6 \pm 10.5 \mathrm{mg} \mathrm{g}^{-1}\right)$ but lower $\mathrm{Fe}_{\text {oxalate }}\left(4.3 \pm 0.1 \mathrm{mg} \mathrm{g}^{-1}\right)$ and $\mathrm{Al}_{\text {oxalate }}\left(2.9 \pm 1.6 \mathrm{mg} \mathrm{g}^{-1}\right)$ contents, representing amorphous Fe- and Al- (hydro)oxides, than sediment and silicate soils and geochemical parameters were always significantly different from silicate soils (Table S2). Soil C (SOC), total N (TN) and P (TP) contents increased

215 in the order sediment $<$ limestone $<$ silicate soils and were lowest in sediment soils (SOC: $22.6 \pm 15.3 \mathrm{mg} \mathrm{g}^{-1}$, TN: $3.4 \pm 2.4 \mathrm{mg} \mathrm{g}$ ${ }^{1}$, TP: $0.5 \pm 0.3 \mathrm{mg} \mathrm{g}^{-1}$ ) than in silicate soils (SOC: $43.0 \pm 31.5 \mathrm{mg} \mathrm{g}^{-1}, \mathrm{TN}: 2.6 \pm 1.6 \mathrm{mg} \mathrm{g}^{-1}$, TP: $0.7 \pm 0.4 \mathrm{mg} \mathrm{g}^{-1}$ ). Soil C:N was

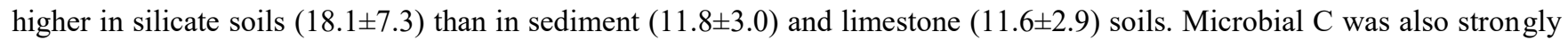
affected by bedrock, with lower $C_{\text {mic }}$ in sediment soils $\left(0.6 \pm 0.3 \mathrm{mg} \mathrm{g}^{-1}\right)$ than in limestone $\left(1.0 \pm 0.6 \mathrm{mg} \mathrm{g}^{-1}\right)$ and silicate $\left(1.1 \pm 0.8 \mathrm{mg} \mathrm{g}^{-1}\right)$ soils. Bedrock had significant effects on bacterial PLFA contents but not on fungal PLFA content and the 
https://doi.org/10.5194/bg-2022-41

Preprint. Discussion started: 22 February 2022

(c) Author(s) 2022. CC BY 4.0 License.

ratio of bacterial to fungal PLFA. Microbial C:N imbalance was lower in sediment soils than in limestone and silicate soils and microbial N:P imbalance was lower in sediment and silicate soils than in limestone soils. $\mathrm{NaOH}$-extractable protein and FAA increased in the order limestone $=$ sediment $<$ silicate. In limestone soils $\mathrm{NaOH}$-extractable protein was lower $\left(68.5 \pm 55.5 \mu \mathrm{g} \mathrm{N} \mathrm{g}^{-1}\right)$ than in sediment $\left(80.8 \pm 47.65 \mu \mathrm{g} \mathrm{N} \mathrm{g}^{-1}\right)$ and silicate $\left(146.9 \pm 107.65 \mu \mathrm{g} \mathrm{N} \mathrm{g}^{-1}\right)$ soils. This corresponds to lower protein depolymerization rates in limestone $\left(32.2 \pm 23.9 \mu \mathrm{g} \mathrm{N} \mathrm{g}^{-1} \mathrm{~d}^{-1}\right)$ and sediment soils $\left(51.3 \pm 58.7 \mu \mathrm{g} \mathrm{N} \mathrm{g}^{-1} \mathrm{~d}^{-1}\right)$ than in silicate soils $\left(181.5 \pm 172.6 \mu \mathrm{g} \mathrm{N} \mathrm{g}^{-1} \mathrm{~d}^{-1}\right)$ (Figure S2). Highly similar patterns to those of protein depolymerization were observed for FAA-N uptake (Figure S1). In contrast, leucine-amino peptidase activity was significantly higher in limestone soils $(0.93 \pm 0.74)$ than in sediment $\left(0.29 \pm 0.49 \mu \mathrm{mol} \mathrm{g}^{-1} \mathrm{~h}^{-1}\right)$ and silicate $\left(0.18 \pm 0.27 \mu \mathrm{mol} \mathrm{g}^{-1} \mathrm{~h}^{-1}\right)$ soils. Mean residence times (MRT) of FAA were not varying significantly between the three bedrock types (Figure S2).

Effects of land use on the organic $\mathrm{N}$ cycle were analyzed for 22 sites comprising woodland, grassland and cropland mineral soils (Table S2). Soil pH was significantly lower in woodland soils $(6.0 \pm 1.5)$ than in grassland $(6.7 \pm 1.3)$ and cropland soils (6.9 \pm 1.2$)$. Root biomass and root $\mathrm{C}: \mathrm{N}$ ratio as well as SOC, DOC, microbial $\mathrm{C}$ and bacterial biomass (PLFA $_{\text {gram }}$, PLFA $A_{\text {gram-, }}$ PLFA $A_{\text {Bacteria }}$ ) were significantly affected by land use and lower in cropland soils compared to woodland soils. $\mathrm{CEC}, \mathrm{Al}_{\text {oxalate }}, \mathrm{Fe}_{\text {oxalate }}$, Fed-o, fungal biomass $\left(\mathrm{PLFA}_{\text {fungi }}\right)$ and fungi:bacteria PLFA ratio (PLFA fungi:bacteria) were not affected by land use. We found no significant effect of land use on soil total $\mathrm{N}$ content, but proportions of dissolved organic and inorganic $\mathrm{N}$ species varied with land use (Figure S4). DON accounted for $61 \%$ of total dissolved $\mathrm{N}$ in grassland soils and $50 \%$ in woodland soils. In contrast, in cropland soils dissolved $\mathrm{N}$ was dominated by $\mathrm{NO}_{3}{ }^{-}(69 \%)$. FAA-N was significantly lower in cropland soils $\left(1.4 \pm 0.64 \mu \mathrm{g} \mathrm{N} \mathrm{g}^{-1}\right)$ than in grassland $\left(4.15 \pm 5.16 \mu \mathrm{g} \mathrm{N} \mathrm{g}^{-1}\right)$ and woodland soils $\left(3.23 \pm 3.71 \mu \mathrm{g} \mathrm{N} \mathrm{g}^{-1}\right.$ ) (Table S2). The proportion of FAA-N in DON increased in the order cropland $(21.9 \%)<$ grassland $(32.0 \%)=$ woodland $(33.0 \%)$. $\mathrm{NaOH}$-extractable protein showed significant differences between cropland and woodland 240 soils and decreased in the order woodland soils $\left(101.7 \pm 47.4 \mu \mathrm{g} \mathrm{N} \mathrm{g}^{-1}\right)>$ grassland $\left(93.8 \pm 41.3 \mu \mathrm{g} \mathrm{N} \mathrm{g}{ }^{-1}\right)>$ cropland $\left(58.6 \pm 52.3 \mu \mathrm{g} \mathrm{N} \mathrm{g}^{-1}\right)$ soils. Gross protein depolymerization rates were significantly lower in cropland soils $(32.9 \pm 27.8 \mu \mathrm{g} \mathrm{N}$ $\left.\mathrm{g}^{-1} \mathrm{~d}^{-1}\right)$ compared to grassland $\left(83.7 \pm 124.4 \mu \mathrm{g} \mathrm{N} \mathrm{g}^{-1} \mathrm{~d}^{-1}\right)$ and woodland soils $\left(72.2 \pm 79.6 \mu \mathrm{g} \mathrm{N} \mathrm{g}^{-1} \mathrm{~d}^{-1}\right)$ (Figure S1). Leucineamino peptidase activity increased in the order cropland=grassland $>$ woodland, however only woodlands $\left(0.34 \pm 0.52 \mu \mathrm{mol} \mathrm{g}^{-1}\right.$ $\left.\mathrm{h}^{-1}\right)$ were significantly lower than grasslands $(0.61 \pm 0.78)$ and croplands $\left(0.46 \pm 0.6 \mu \mathrm{mol} \mathrm{g}^{-1} \mathrm{~h}^{-1}\right)$ (Figure S1, Table S2). Mean 245 residence times of FAA were not affected by land use type (Figure S3, Table S2).

At 13 forest sites we sampled the corresponding organic horizons. Differences between the organic horizons and the underlying mineral soil were analyzed by paired t-tests (Table S2). Soil pH was significantly lower in organic soil horizons than in mineral soil horizons. Soil bacterial and fungal PLFA contents were not significantly different between mineral and organic soil horizons. CEC as well as soil C (SOC, DOC), N (total N, DON, NH4+, NO3-, FAA-N) and P (TP, DOP, TOP) 250 contents were higher in organic soil horizons than in mineral horizons. Organic horizons showed significantly higher $\mathrm{NaOH}-$ extractable protein contents $\left(347.6 \pm 58.9 \mu \mathrm{g} \mathrm{N} \mathrm{g}^{-1}\right)$ than mineral soil layers $\left(159.1 \pm 122.4 \mu \mathrm{g} \mathrm{N} \mathrm{g}^{-1}\right)$. Leucine-amino peptidase activity, protein depolymerization and FAA-uptake were significantly higher in organic soil layers than in the underlying mineral soil layers. Protein depolymerization rates in organic layers $\left(926.9 \pm 656.0 \mu \mathrm{g} \mathrm{N} \mathrm{g}^{-1} \mathrm{~d}^{-1}\right)$ exceeded those in mineral 
layers $\left(167.45 \pm 159.5 \mu \mathrm{g} \mathrm{N} \mathrm{g}^{-1} \mathrm{~d}^{-1}\right)$ by 5 -fold. Leucine-amino peptidase activity was 6-fold higher in organic soil layers $\left(0.29 \pm 0.11 \mu \mathrm{mol} \mathrm{g}{ }^{-1} \mathrm{~h}^{-1}\right)$ than in mineral soil layers $\left(0.05 \pm 0.02 \mu \mathrm{mol} \mathrm{g}^{-1} \mathrm{~h}^{-1}\right)$.

Correlation analyses of protein depolymerization showed positive relationships with amorphous $\mathrm{Fe}$ and $\mathrm{Al}$ minerals $\left(\mathrm{Fe}_{\text {oxalate }}, \mathrm{Al}_{\text {oxalate }}\right)$, soil organic matter (Corg, total $\left.\mathrm{N}\right), \mathrm{NaOH}$-extractable protein and microbial biomass (Cmic, PLFA) (Figure 3, Table S3). NaOH extractable protein content increased with $\mathrm{SOC}, \mathrm{TN}$, root biomass and amorphous $\mathrm{Fe}$ - and $\mathrm{Al}$ (hydr)oxides (Table S3, Figure 3). Soil $\mathrm{pH}$ was negatively correlated with gross depolymerization and $\mathrm{NaOH}$-extractable protein but positively to peptidase activity (Figure 3). Peptidase activity was positively related to microbial C, CEC, clay and silt content. However, across all sites as well as within subgroups we found no significant correlation between peptidase activity and protein depolymerization rates (Figure S5). In order to further examine the potential edaphic controls on protein depolymerization rates in mineral soils as well as interaction effects with land use we used multiple linear regression
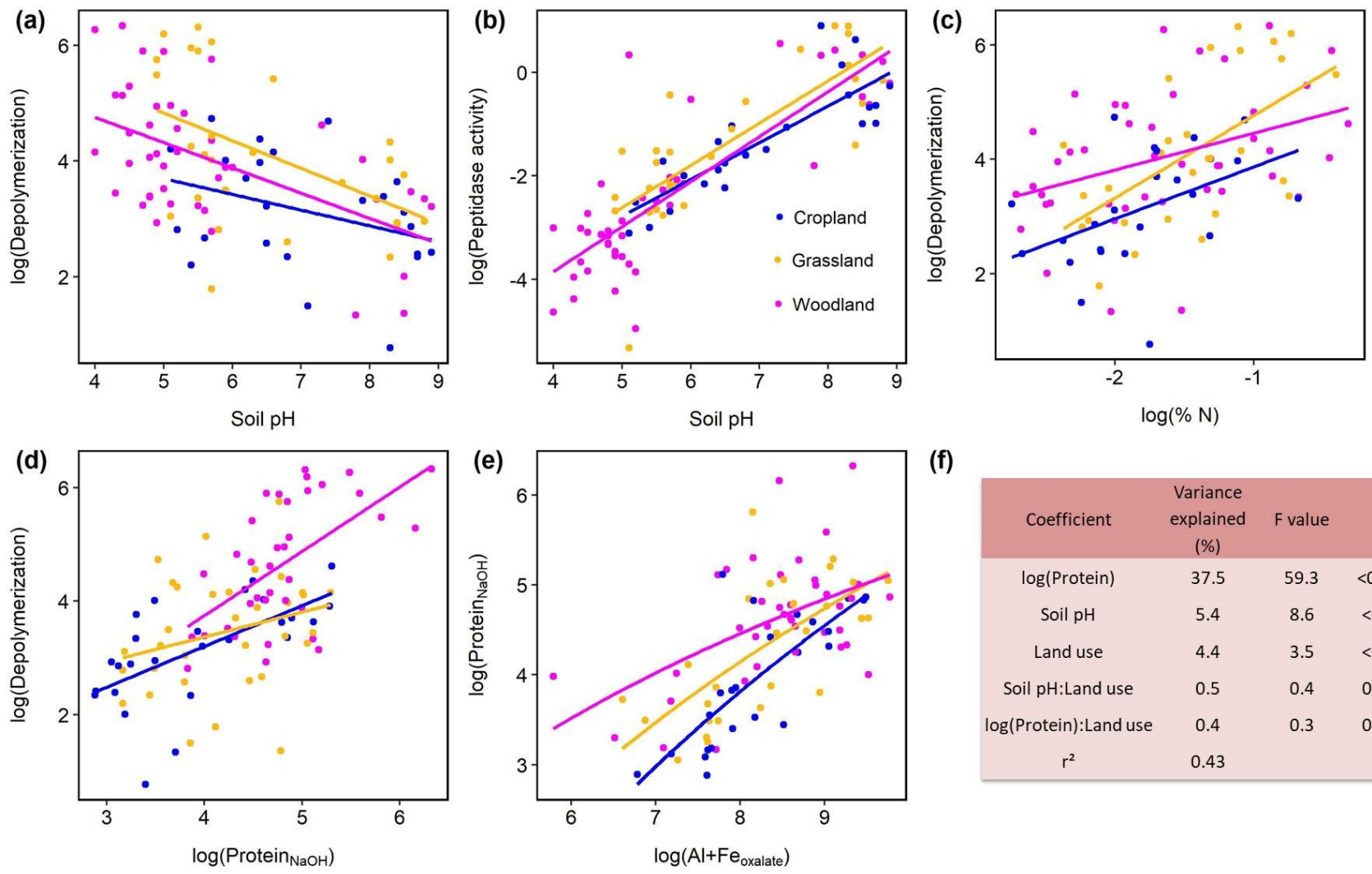

(f)

\begin{tabular}{|cccc|}
\hline Coefficient & $\begin{array}{c}\text { Variance } \\
\text { explained } \\
(\%)\end{array}$ & F value & $p$ \\
\hline $\log$ (Protein) & 37.5 & 59.3 & $<0.001$ \\
Soil pH & 5.4 & 8.6 & $<0.01$ \\
Land use & 4.4 & 3.5 & $<0.05$ \\
Soil pH:Land use & 0.5 & 0.4 & 0.679 \\
$\log$ (Protein):Land use & 0.4 & 0.3 & 0.721 \\
$r^{2}$ & 0.43 & & \\
\hline
\end{tabular}

Figure 3 Effects of soil properties on gross protein depolymerization rates in mineral soils. Relationship of pH and (a), $\log ($ Protein depolymerization) and (b), $\log$ (leucine-amino peptidase activity). (c), Relationship of soil total $N$ and protein depolymerization rate (d), Relationship of $\mathrm{NaOH}$-extractable protein and protein depolymerization rate. Color codes indicate land use type. (e), Relationship of oxalate extractable $\mathrm{Al}$ and $\mathrm{Fe}$ and $\mathrm{NaOH}$-extractable protein. (f), Analyses of variance of the most parsimonious linear regression model of $\log$ (gross protein depolymerization rate) explained by soil properties, land use and their interaction effects $(n=95)$. Total model fit is given as adjusted $\mathbf{r}^{2}$. 
https://doi.org/10.5194/bg-2022-41

Preprint. Discussion started: 22 February 2022

(c) Author(s) 2022. CC BY 4.0 License.

\section{(c) (i)}

analyses. The most parsimonious model included a strong positive effect of $\mathrm{NaOH}$-extractable protein explaining $37 \%$ of the variance (Figure 3). Soil $\mathrm{pH}$ had a negative effect on depolymerization rates and parameter estimates for land use increased in the order cropland<grassland<woodland. Interaction effects between edaphic properties and land use were not significant. Linear mixed effect models with land use as random factor revealed the same main predictors and the final model explained $69 \%$ of the variation (Table S4).

Climate effects on depolymerization rates were analysed by linear regression analyses including climate parameters, land use and interaction effects. We found significant effects of MAT, MAP and their interaction effect (MAP:MAT) (Table S5). Land use had no significant effect, as shown by the strong negative correlation between depolymerization and MAT across the three studied land use types (Figure 4). The model explained about $42 \%$ of the variance. Although, the climatic humidity index (MAP:PET) expressed as MAP over potential evapotranspiration (PET) was not included in the most parsimonious model the strong non-linear increase of depolymerization rates with climatic humidity $\left(\mathrm{r}^{2}=0.632, \mathrm{p}<0.001\right)$ across all sites and land use types was striking (Figure 4). The most parsimonious linear mixed effect model included land use as random factor and showed a strong negative effect of MAT as well as a positive effect of MAP. The model explained about $47 \%$ of the variance. The interaction of MAT:MAP was not significant.

\subsection{Interactive effects of edaphic properties and climate}

Since soil parent material, which is a main driver of soil geochemical properties, is not uniformly distributed across the sampled transect, climate effects (MAT and MAP) on gross protein depolymerization rates, leucine-amino peptidase activity and $\mathrm{NaOH}$-extractable protein were analysed by partial regression analyses controlled for geochemical parameters (Figure 4). We found a negative zero-order correlation between protein depolymerization rates and MAT $(r=-0.63, p<0.01)$. A significant decrease of the correlation coefficient was observed when removing correlations with $\mathrm{Al}, \mathrm{Fe}$ or the sum of oxalate extractable $\mathrm{Fe}$ and $\mathrm{Al}$ (Figure 4). Leucine-amino peptidase was positively correlated to MAT $(\mathrm{r}=0.34, \mathrm{p}<0.05)$.

285 After removing the correlations with soil $\mathrm{pH}$ or $\mathrm{Al}$ we found a negative correlation between peptidase activity and MAT. Removal of the correlation with soil $\mathrm{P}$ content significantly increased the positive correlation between peptidase activity and MAT. NaOH-extractable protein was negatively correlated to MAT $(r=-0.53, p<0.01)$. The correlation coefficient was significantly decreased by removing the correlations with $\mathrm{Al}$ and the sum of oxalate extractable $\mathrm{Al}$ and Fe. All zero-order correlations with MAT decreased significantly after removing the effects of all used soil geochemical parameters. Mean annual precipitation was weakly positively correlated with protein depolymerization rates $(r=0.29, p<0.05)$. The removal of correlations with geochemical parameters did not change the correlation coefficient significantly. Leucine-amino peptidase activity was not correlated to MAP; however the removal of soil $\mathrm{pH}$ or $\mathrm{Al}$ increased the correlation coefficient significantly, inducing a weak positive correlation between leucine-amino peptidase activity and MAP. NaOH-extractable protein was positively correlated to MAP $(r=0.46, p<0.01)$ and the removal of correlations with geochemical parameters had no significant effect. 

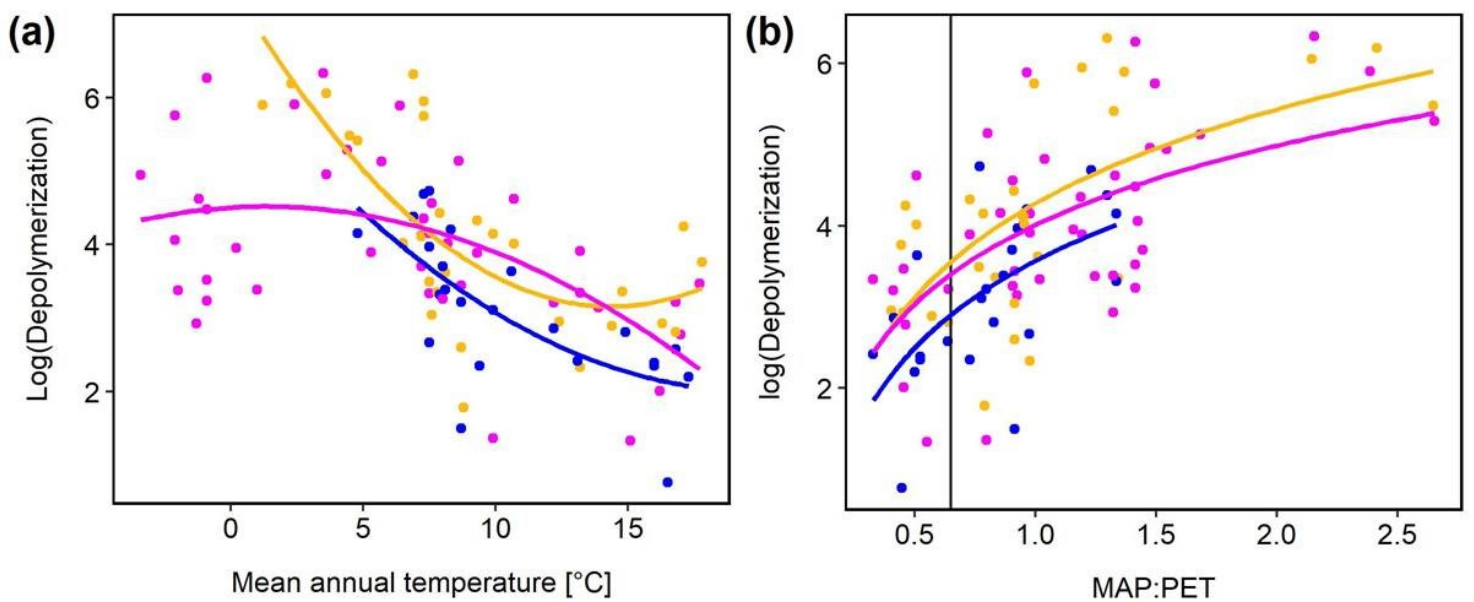

- Cropland - Grassland —Woodland

(c)

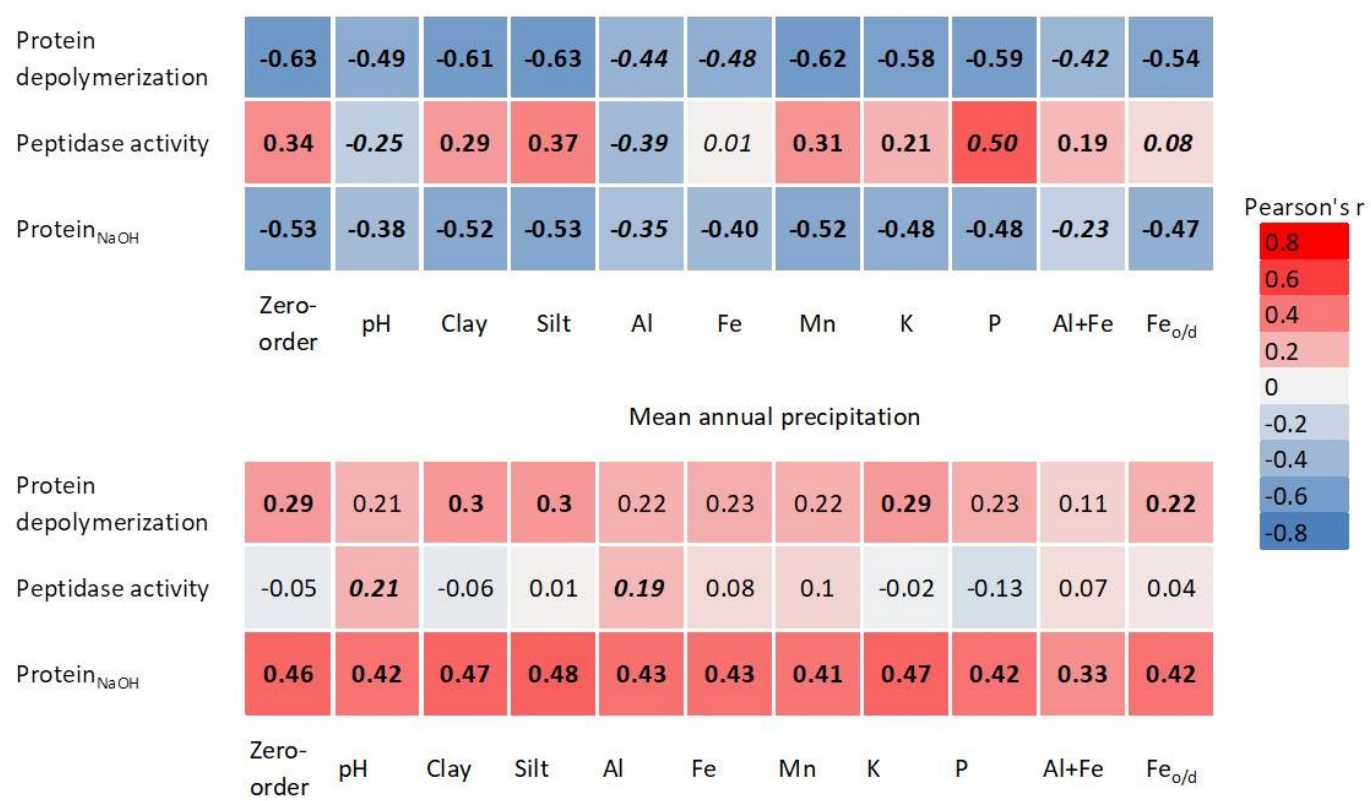

Figure 4 Climate effects on gross protein depolymerization. (a), Relationship between the natural logarithm of gross protein depolymerization and 2 nd polynomial regression fit for cropland (adjusted $\mathbf{r}^{2}=0.455, \mathbf{p}<0.001, \mathrm{n}=\mathbf{2 4}$ ), grassland $\left(r^{2}=0.480, p<0.001, n=28\right)$ and woodland $\left(r^{2}=0.219, p<0.01, n=48\right)$ soils. (b), Relationship between the natural logarithm of gross protein depolymerization rates and the ratio of mean annual precipitation over potential evapotranspiration (MAP:PET) and regression fit $(y=\log (x))$ for cropland (adjusted $\left.\mathbf{r}^{2}=0.330, p<0.01, n=24\right)$, grassland (adjusted $r^{2}=0.371, p<0.001, n=28$ ) and woodland (adjusted $\left.r^{2}=0.318, p<0.001, n=48\right)$ soils. The vertical line indicates the transition from arid to humid climate conditions (MAP:PET $=0.65)$. (c), zero-order and partial correlations (Pearson's $r$ ) between climate variables (MAT and MAP) and organic $\mathbf{N}$ cycling (protein depolymerization rate, leucine-amino peptidase activity and Protein $_{\mathrm{NaOH}}$ ) controlled for geochemical variables). Significant correlations are indicated by bold numbers. Significant changes of the correlation coefficients compared to the zero-order correlation are indicated by italic numbers. 
https://doi.org/10.5194/bg-2022-41

Preprint. Discussion started: 22 February 2022

(c) Author(s) 2022. CC BY 4.0 License.

(c) (i)

\subsection{Path analyses}

The a priori model was constructed according to the hypothesis illustrated in Figure 1. After removing insignificant paths the model contained $\mathrm{NaOH}$-extractable protein, soil $\mathrm{pH}$, amorphous $\mathrm{Fe}$ and $\mathrm{Al}$ and $\mathrm{MAP}\left(\mathrm{X}^{2}=2.49, \mathrm{p}=0.288\right.$; $\mathrm{RMSEA}=$ 0.048 , SRMR $=0.023$ ). The revised model explained $43 \%$ of the variance in gross depolymerization and $49 \%$ of the variance in $\mathrm{NaOH}$-extractable protein. Protein depolymerization in mineral soils was highly dependent on $\mathrm{NaOH}$-extractable protein.

305 Soil $\mathrm{pH}$ had direct and indirect (via $\mathrm{NaOH}$-extractable protein) negative effects on depolymerization rates (Figure 5). MAP and amorphous $\mathrm{Fe}$ and $\mathrm{Al}$ had positive effects on $\mathrm{NaOH}$-extractable protein and thereby positive indirect effects on protein depolymerization. The total effects (direct effects + indirect effects) of the model parameters on protein depolymerization increased in the order amorphous $\mathrm{Fe}$ and $\mathrm{Al}<$ soil $\mathrm{pH}<\mathrm{MAP}<\mathrm{NaOH}$-extractable protein. The model explained $49 \%$ of the variation of $\mathrm{NaOH}$-extractable protein and $43 \%$ of the variation of protein depolymerization rates.

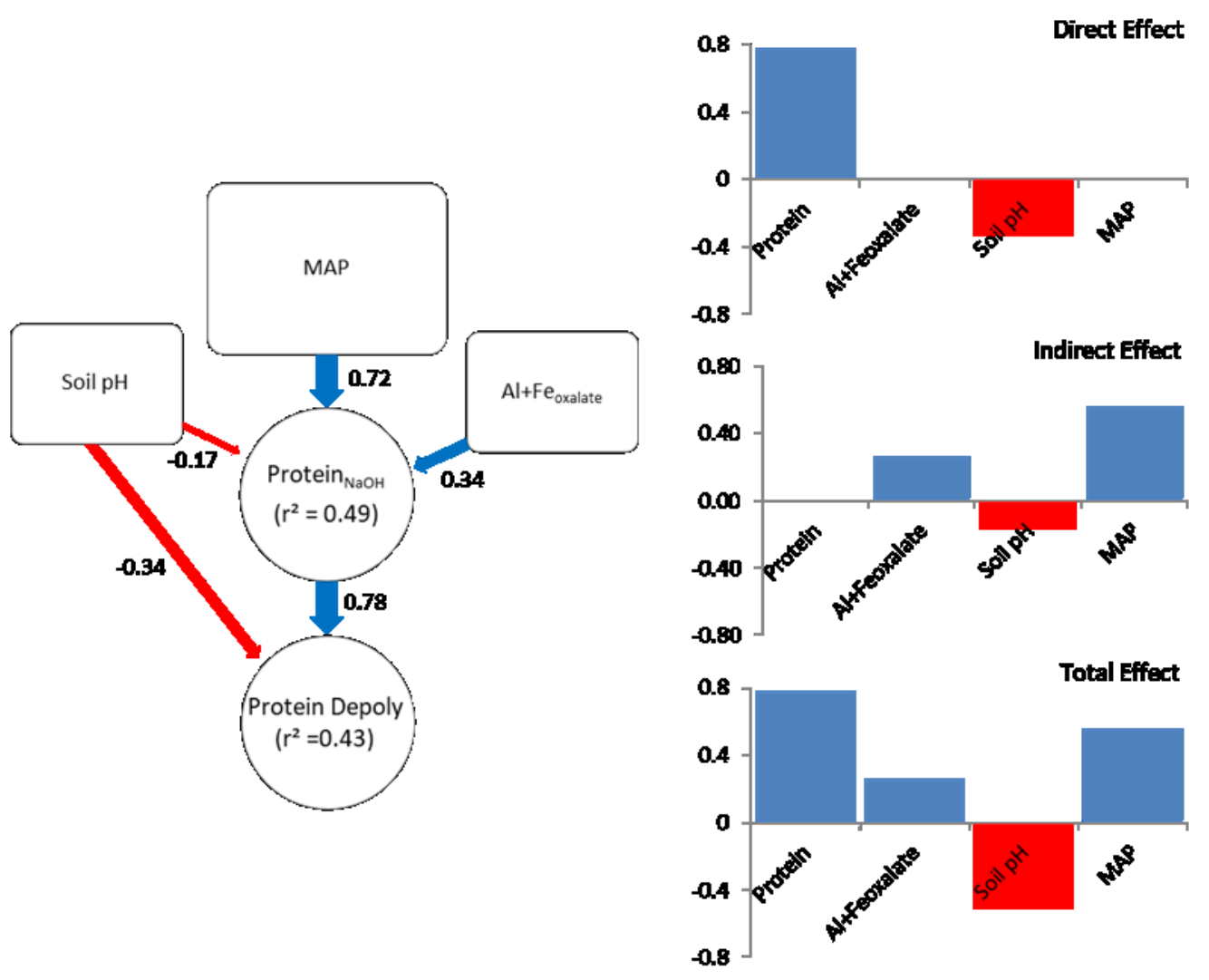

Figure 5 Direct and indirect effects in gross protein depolymerization rates. Controls of Path analyses for gross protein depolymerization rates in mineral soils and coefficients for direct, indirect and total effects $(n=91)$. Significant effects $(p<0.05)$ are indicated by black arrows and effect sizes are indicated by line width. Numbers beside arrows indicate the standardized parameter estimates. Numbers within boxes indicate the variance explained by the model. 
https://doi.org/10.5194/bg-2022-41

Preprint. Discussion started: 22 February 2022

(c) Author(s) 2022. CC BY 4.0 License.

(c) (i)

\section{Discussion}

\subsection{Land use and soil horizon effects on protein depolymerization}

Across all land use types and soil horizons we found support for our hypothesis that gross protein depolymerization is controlled by $\mathrm{N}$ availability which increased with soil organic matter (SOM) contents from Mediterranean to temperate and boreal ecosystems (Table S3). SOM has often been found to decline in cropland soils due to reduced root and litter input and due to tillage (Six and Jastrow, 2002). As a consequence $\mathrm{NaOH}$-extractable protein and gross depolymerization were lowest in cropland soils compared to grassland and woodland soils across all biomes. We suggest that in the studied cropland soils depolymerization was likely limited by the availability of proteins, as SOM declines, though we found no differences between total $\mathrm{N}$ contents of the three land use types (Table S2). However, in cropland soils, depolymerization was strongly correlated with root biomass which may indicate that easily available $\mathrm{C}$ compounds introduced into soils by root exudation and root turnover enable microorganisms to mine for organic N (Angst et al., 2018). In grassland soils we observed an increase of protein depolymerization rates with lower root $\mathrm{C}: \mathrm{N}$ ratios, which was accompanied by a shift in microbial community composition from high fungi:bacteria ratios in $\mathrm{N}$-limited grasslands towards lower fungal abundance in $\mathrm{N}$-rich grasslands (Table S3). Decreases in fungi:bacteria ratios have also been reported with increases in N availability e.g. due to fertilization (Grayston et al., 2001; De Vries et al., 2006). However, this pattern in protein depolymerization was not confirmed to be related to soil $\mathrm{C}: \mathrm{N}$, or to microbial C:N imbalance defined as the ratio of soil C:N over microbial C:N. In woodland soils, high $\mathrm{SOM}$ and $\mathrm{NaOH}$-extractable protein contents did not translate into higher depolymerization rates compared to grassland soils. We suggest that the effect of SOM on depolymerization rates might be overridden by the large heterogeneity in forest edaphic properties e.g. soil $\mathrm{pH}$ ranging from 4.0 to 8.9. Gross depolymerization might be further constrained by the lower peptidase activities found in woodland soils compared to grassland and cropland soils (Table S2) due to the typically lower soil $\mathrm{pH}$ (Sinsabaugh et al., 2008). Moreover, at acidic soil $\mathrm{pH}$ mobilization of $\mathrm{Al}^{3+}$ might promote precipitation of proteins and of proteolytic enzymes, which restricts enzymatic cleavage (Scheel et al., 2008). Overall, land use had no effect on the response of depolymerization rates to soil properties and explained less than $5 \%$ of the variance, as shown by multiple linear regressions (Figure 3, Table S5), and might therefore be only a minor control of soil organic $\mathrm{N}$ cycling across large scales. The positive effect of substrate availability on depolymerization rates was also confirmed by the high gross protein depolymerization rates observed in organic horizons in boreal and alpine biomes which exceeded those in the underlying mineral soils by 5 -fold. In contrast to findings from Mooshammer at al. (2012) for decomposing litter, our data revealed no indication that resource $\mathrm{C}: \mathrm{N}$ or microbial $\mathrm{C}: \mathrm{N}$ imbalance affected protein depolymerization rates in organic soils. However, the increasing depolymerization rates with latitude though vegetation $\mathrm{N}$ limitation increases and the missing

340 effects of resource C:N ratio and microbial C:N imbalance indicate differential limitation of plants and soil microbes across large spatial scales as proposed by Capek et al. (2018). 
https://doi.org/10.5194/bg-2022-41

Preprint. Discussion started: 22 February 2022

(c) Author(s) 2022. CC BY 4.0 License.

\section{(c) (i)}

\subsection{Substrate limitation of protein depolymerization is controlled by organo-mineral interactions}

Across all land use types $\mathrm{NaOH}$-extractable protein and soil $\mathrm{pH}$ were the main predictors for gross protein depolymerization in mineral soils, indicating that soil properties that determine protein availability such as texture, mineral assemblage or soil $\mathrm{pH}$ need to be considered when addressing controls of soil organic N cycling. Gross protein depolymerization was lower in soils developed on limestone than in soils developed on sediments or silicates, which is emphasized by the inverse relationship between depolymerization rates and soil $\mathrm{pH}$ (Figure 3). Moreover, depolymerization rates decreased with increasing clay content. Proteins can be adsorbed to clay surfaces by electrostatic interactions between positively charged amino acid side chains and siloxane surfaces of clay minerals (Staunton and Quiquampoix, 1994; Quiquampoix and Ratcliffe, 1992). Sorption experiments in artificial soils showed that at neutral soil $\mathrm{pH}(>7)$ clay minerals are the main

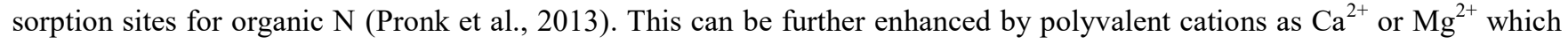
can bridge the negative charges of clay mineral surfaces and proteins (Cao et al., 2011; Lützow et al., 2006). Aside from the stabilization on mineral surfaces, high clay contents, as found in limestone soils, promote soil aggregation and thereby occlusion of organic matter and proteins rendering them inaccessible for enzymatic attack (Lützow et al., 2006). In contrast

355 Fe- and Al- oxyhydroxides, the main sorption sites for SOM at acidic $\mathrm{pH}$, were positively correlated to gross depolymerization rates. SOM accumulation is usually higher in acid soils due to ligand exchange between protonated hydroxyl groups of Fe- and Al- minerals and carboxyl groups of organic molecules (Gu et al., 1994; Kleber et al., 2005; Kaiser and Guggenberger, 2000). In acidic soils, column experiments with embedded goethite revealed that sufficiently large amounts of stabilized $\mathrm{C}$ were re-dissolved by progressing percolation of dissolved OM and consequent exchange of adsorbed compounds, indicating that stabilized compounds are available for microbial utilization (Leinemann et al., 2018). This is further supported by the strong positive correlation between $\mathrm{NaOH}$-extractable protein and amorphous $\mathrm{Fe}$ - and $\mathrm{Al}-$ oxyhydroxides (Table S3), since $\mathrm{NaOH}$ mainly extracts loosely bound proteins (Wattel-Koekkoek et al., 2001). However, Fe- and Al oxyhydroxides remained as a significant parameter in linear models and path analyses and should therefore be considered as important predictor for the potential of a soil to retain and accumulate SOM, which promotes microbial live and decomposition. However, the total $\mathrm{N}$ pool size was not significantly different between soils developed on the three bedrock types but $\mathrm{NaOH}$-extractable protein increased on the order limestone $<$ sediment $<$ silicate. In contrast $\mathrm{NaOH}$ extractable protein accounted for $4.4 \pm 1.7 \%$ of total $\mathrm{N}$ in sediment soils and for $6.4 \pm 3 \%$ in silicate soils. This could be either attributed to lower extraction efficiency of proteins with $0.5 \mathrm{M} \mathrm{NaOH}$ from clay minerals at high soil $\mathrm{pH}$ or to an increase of non-hydrolysable organic $\mathrm{N}$. The studied limestone soils were characterized by higher amounts of crystalline iron $\left(\mathrm{Fe}_{\mathrm{d}-\mathrm{o}}\right)$, namely hematite which forms almost irreversible interactions with SOM ( $\mathrm{Gu}$ et al., 1995), even at high soil $\mathrm{pH}$ due to formation of coordination complexes between carboxyl groups and Fe atoms (Koutsoukos et al., 1983; Quiquampoix, 2000). The formation of strong complexes on crystalline Fe minerals is also supported by findings of Mikutta et al. (2010), who showed an increase of non-hydrolysable peptide- $\mathrm{N}$ with the proportion of crystalline $\mathrm{Fe}$ minerals across a soil chronosequence. 
https://doi.org/10.5194/bg-2022-41

Preprint. Discussion started: 22 February 2022

(c) Author(s) 2022. CC BY 4.0 License.

\section{(c) (i)}

From linear regression and path analyses soil $\mathrm{pH}$ was revealed as the second most important predictor of gross depolymerization rates. Soil $\mathrm{pH}$ affects electrostatic interactions between mineral surfaces and proteins. Sorption of proteins on clay and Fe-mineral surfaces is usually highest close to the isoelectric point of a specific protein, when the net charge is zero and repulsion from charged surfaces is smallest. However, due to the complex nature of proteins including different functional groups and their tertiary structure isoelectric points range from $\mathrm{pH} 1$ for pepsin to $\mathrm{pH} 11$ for lysozyme, making predictions for soil proteins at large impossible. Sorption of bovine and human serum albumin on montmorillonite peaked at $\mathrm{pH} \sim 5$ whereas adsorption of cytochrome $\mathrm{c}$ or ribonuclease on hematite peaked at pH 8 to 10 (Khare et al., 2006; Koutsoukos et al., 1983; Quiquampoix and Ratcliffe, 1992).

However, the negative effect of soil $\mathrm{pH}$ on gross depolymerization is in sharp contrast to the increase of peptidase activity with soil $\mathrm{pH}$. To allow comparisons between enzyme activity and depolymerization rates enzyme activities were measured in unbuffered soil slurries at natural soil $\mathrm{pH}$ compared to enzyme activities measured at same $\mathrm{pH}$ in acetate buffer $(\mathrm{pH}$ 5.2). Hence, unbuffered peptidase activities were highest in limestone soils close to the $\mathrm{pH}$ optima of proteolytic enzymes at about 8 (Sinsabaugh et al., 2008) (Figure S5). The lack of correlation between gross depolymerization and peptidase activity implies that gross protein depolymerization rates are rather substrate limited than enzyme limited and that differences in protein depolymerization rates between alkaline, neutral and acidic soils are due to changes in substrate (protein) availability rather than due to changes in microbial community structure and enzymatic activity. Even when peptidase was measured at the same $\mathrm{pH}$, potential peptidase activity was higher in limestone soils compared to sediment and silicate soils (Table S2, Figure S6), which implies enhanced microbial enzyme excretion in limestone soils in response to lower protein availability/concentration.

The generally low protein depolymerization rates in limestone soils are in accordance to our previous findings from soils

395 developed on limestone and silicate bedrock in Austria (Noll et al., 2019b), demonstrating that soil parent material predetermines depolymerization rates on regional and continental scales. We assume that in limestone soils proteins are strongly stabilized on phyllosilicates and crystalline Fe-oxides or occluded within soil aggregates rendering them inaccessible for proteolytic attack. Soil microorganisms mitigate this N-limitation by mining for more recalcitrant SOM (Chen et al., 2014) as shown by the enhanced excretion of amino peptidase in limestone soils. With increasing amorphous $\mathrm{Fe}$ - and Al-

400 oxyhydroxides the sorption capacity of soils increases strongly due to their higher surface area (Kaiser and Guggenberger, 2003) facilitating accumulation of SOM. However, given the strong correlation between $\mathrm{NaOH}$-extractable protein and amorphous Fe- and Al- oxyhydroxides, our data clearly shows that soil mineral assemblage is a crucial driver of soil organic $\mathrm{N}$ stocks and dynamics across large scales.

\subsection{Climate drives protein depolymerization by affecting mineral weathering and plant productivity}

405 Climate is a major control on mineral weathering and net primary productivity and thereby affects protein stabilization and input of fresh OM by plants. Across the studied climate transect gross protein depolymerization rates decreased with MAT and increased with MAP, respectively the climatic humidity index (MAP:PET). As demonstrated by the partial correlations, 
https://doi.org/10.5194/bg-2022-41

Preprint. Discussion started: 22 February 2022

(c) Author(s) 2022. CC BY 4.0 License.

\section{(c) (i)}

part of the negative effect of MAT on depolymerization rates can be explained by concomitant changes in amorphous $\mathrm{Al}$ and Fe oxyhydroxides and soil $\mathrm{pH}$ which affect protein availability (Figure 4). The important role of soil geochemical properties on protein stabilization is underpinned by the even stronger effect of soil properties on the relation of MAT and $\mathrm{NaOH}-$ extractable protein (Figure 4). In the Mediterranean region limestone derived red soils are predominating. The so called "Terra Rossa" soils are characterized by high soil pH, high clay contents and higher amounts of crystalline Fe as well as a low $\mathrm{Fe}_{\text {oxalate }}: \mathrm{Fe}_{\text {dithionite }}$ ratio, caused by the preferential formation of the Fe-oxide hematite over the Fe-hydroxide goethite during the summer dry period (Yaalon, 1997). As described above, these specific soil properties might foster stabilization of proteins and thereby constrain gross depolymerization. Under more humid conditions soil $\mathrm{pH}$ drops due to leaching of base cations (e.g. $\mathrm{Ca}^{2+}$ ) and more intensive chemical weathering causes higher amounts of charged mineral surfaces as amorphous Fe- and Al oxyhydroxides (Doetterl et al., 2015). This increase in soil acidification with latitude is further facilitated by predominance of silicate bedrocks in Northern Europe. Although MAP is an important driver of soil weathering and thereby affects soil $\mathrm{pH}$ and formation of charged mineral surfaces the positive effect of MAP on depolymerization rates and proteins was not significantly biased by soil properties (Figure 4). However, the weak effects of $\mathrm{Fe}$ and $\mathrm{Al}$ oxyhydroxides on the relation between protein depolymerization and MAP, or between $\mathrm{NaOH}$-extractable protein and MAP might indicate the role of MAP in soil mineral formation during pedogenesis. Particularly in arid and sub-arid biomes precipitation determines plant net primary production (Yang et al., 2008; Del Grosso et al., 2008) and thereby the input of fresh organic matter into the soil. This might further explain the strong relationship between $\mathrm{NaOH}$-extractable protein and MAP, as indicated by linear models and path analyses and is further supported by the proximate increase in depolymerization with the climatic humidity index (Figure 4). The logarithmic response implies that the limiting effect of MAP is stronger under sub-arid conditions, which is in accordance to findings showing that in water limited regions NPP is strongly controlled by MAP (Yang et al., 2008). Therefore, we conclude that, in sub arid regions in Southern Europe precipitation constrains plant biomass production and consequently OM input into soils. In contrast, our results reveal that the increase of gross depolymerization with MAT is biased by changes in soil parent material across the studied transect, while MAP likely controls net primary productivity and mineral weathering (Gislason et al., 2009; La Pierre et al., 2016). Both, partial correlations and path analyses support our hypothesis that climate is a rather indirect control on soil organic nitrogen cycling by its effects on soil geochemistry and soil organic matter accumulation.

Path analysis emphasized the important role of climate and bedrock as pre-determinants of OM stabilization and protein availability and suggested that MAP, soil $\mathrm{pH}$ and $\mathrm{Fe}$ - and $\mathrm{Al}$ - oxyhydroxides are indirect controls on gross depolymerization mediated by protein availability while soil $\mathrm{pH}$ and $\mathrm{NaOH}$-extractable protein were direct controls on gross depolymerization. The indirect effect of MAP exceeded the direct effects of soil mineralogy and $\mathrm{pH}$. However, $\mathrm{NaOH}-$ extractable protein was the main predictor of protein depolymerization rates. The negative direct effect of soil $\mathrm{pH}$ on depolymerization rates is explained by the low solubility of proteins at high soil pH (Franco and Pessôa Filho, 2011) which restricts diffusion throughout the soil matrix and limits accessibility of proteins to enzymatic attack. In contrast, the negative $\mathrm{pH}$ effect on $\mathrm{NaOH}$-extractable protein is attributed to the accumulation of $\mathrm{SOM}$ at acidic soil $\mathrm{pH}$ and the enhanced 
interactions with Fe- and Al- oxyhydroxides (Kaiser and Guggenberger, 2003; Gu et al., 1994). With increasing soil pH amino groups of proteins become de-protonated and thereby proteins become negatively charged which increases the repulsion from negatively charged mineral surfaces and decreases the adsorption to Fe-oxides and phyllosilicates (Cao et al.,

445 2011). Furthermore, soil $\mathrm{pH}$, texture and mineral assemblage are drivers of microbial community composition and affect the availability of other nutrients like P or K (Fierer and Jackson, 2006; Lauber et al., 2008). Neither $\mathrm{Ca}^{2+}$ nor clay was included in the final model, despite their important role in stabilizing soil organic matter (Lützow et al., 2006). We assume that the effects of $\mathrm{Ca}^{2+}$ and clay are outweighed by effects of soil $\mathrm{pH}$ and MAP. Soil $\mathrm{pH}$ decreased from clay rich limestone soils to sediment soils and to more sandy silicate soils and thereby covaried with $\mathrm{Ca}^{2+}$ and clay content, while MAP regulates mineral dissolution and leaching of $\mathrm{Ca}^{2+}$ (Gislason et al., 2009). Land use was also removed from the revised model which is in accordance to results from general linear models, showing that soil properties and climate variables explained a much higher percentage of the variance in gross protein depolymerization. Although path analyses provided an integrative model of controls driving gross protein depolymerization, it offered an incomplete picture. In this study we focused on the large scale patterns, which explained more than $40 \%$ of the variation in organic $\mathrm{N}$ cycling. However, regional or local effects, such as topography, land use history/intensity or plant community composition, were not accessible with this data set, but are likely important controls on organic $\mathrm{N}$ cycling.

\section{Conclusions}

Our results highlight the important role of soil geochemistry when estimating microbial nutrient cycling on continental to global scales, and demonstrate that soil parent material and climate modulate the effects of land use on soil organic $\mathrm{N}$ transformations. The amount of $\mathrm{NaOH}$-extractable protein was identified as an important direct predictor of protein depolymerization rates. In contrast, peptidase activity was a poor proxy of protein depolymerization, but rather a proxy of enzyme production and of microbial $\mathrm{C}$ or $\mathrm{N}$ limitation. Since protein availability and thereby depolymerization is strongly constrained by soil mineral interactions, shifts in climate (precipitation regime) and associated alterations in soil weathering should be considered as drivers of ecosystem $\mathrm{N}$ availability with repercussions on ecosystem $\mathrm{C}$ cycle processes. This also needs to be validated in large-scale coupled biogeochemical climate models to help predict and mitigate global change effects.

\section{Data availability}

All data and codes presented in this paper are available upon reasonable request. 
https://doi.org/10.5194/bg-2022-41

Preprint. Discussion started: 22 February 2022

(C) Author(s) 2022. CC BY 4.0 License.

(c) (i)

\section{Author contribution}

470 LN wrote the paper, conducted fieldwork and laboratory work, analyzed and interpreted the data. SZ, QZ and YH conducted laboratory work, analyzed the data and edited the paper. FH analyzed the data and edited the paper. WW designed the study, interpreted the data and edited the paper.

\section{Competing interests}

The authors declare that they have no competing interests.

\section{Acknowledgements}

We thank Theresa Böckle, Daniel Wasner, Vsevolods Girsovics and Rebecca Lieske for soil sampling and assistance in the lab. We would like to thank Jukka Pumpanen for providing soil samples from the Värriö District Nature Reserve. This project was funded by the Austrian Science Fund (FWF, Project P-28037-B22).

\section{References}

480 Adamczyk, B., Kitunen, V., and Smolander, A.: Polyphenol oxidase, tannase and proteolytic activity in relation to tannin concentration in the soil organic horizon under silver birch and Norway spruce, Soil Biology and Biochemistry, 41, 2085-2093, https://doi.org/10.1016/j.soilbio.2009.07.018, 2009.

Angst, G., Messinger, J., Greiner, M., Häusler, W., Hertel, D., Kirfel, K., Kögel-Knabner, I., Leuschner, C., Rethemeyer, J., and Mueller, C. W.: Soil organic carbon stocks in topsoil and subsoil controlled by parent material, carbon input in the rhizosphere, and microbial-

485 derived compounds, Soil Biology and Biochemistry, 122, 19-30, https://doi.org/10.1016/j.soilbio.2018.03.026, 2018.

Asch, K.: IGME 5000: 1: 5 Million international geological map of Europe and Adjacent Areas-final version for the internet. BGR, Hannover, 2005.

BGR [Bundesanstalt für Geowissenschaften und Rohstoffe]: Soil Regions Map of the European Union and Adjacent Countries 1:5000000 (Version 2.0), Special Publication Ispra. EU catalogue number S.P.I.05.134., 2005.

490 Bohn, U. and Katenina, G.: Karte der natürlichen Vegetation Europas [: Map of the natural vegetation of Europe, Bundesamt für Naturschutz2000.

Brookes, P., Landman, A., Pruden, G., and Jenkinson, D.: Chloroform fumigation and the release of soil nitrogen: a rapid direct extraction method to measure microbial biomass nitrogen in soil, Soil biology and biochemistry, 17, 837-842, 1985.

Callesen, I., Raulund-Rasmussen, K., Westman, C. J., and Tau-Strand, L.: Nitrogen pools and C : N ratios in well-drained Nordic forest

495 soils related to climate and soil texture, Boreal Environment Research, 12, 681-692, 2007.

Cao, Y., Wei, X., Cai, P., Huang, Q., Rong, X., and Liang, W.: Preferential adsorption of extracellular polymeric substances from bacteria on clay minerals and iron oxide, Colloids and Surfaces B: Biointerfaces, 83, 122-127, https://doi.org/10.1016/j.colsurfb.2010.11.018, 2011.

Capek, P. T., Manzoni, S., Kastovska, E., Wild, B., Diakova, K., Barta, J., Schnecker, J., Blasi, C., Martikainen, P. J., Alves, R. J. E.,

500 Guggenberger, G., Gentsch, N., Hugelius, G., Palmtag, J., Mikutta, R., Shibistova, O., Urich, T., Schleper, C., Richter, A., and Santruckova, H.: A plant-microbe interaction framework explaining nutrient effects on primary production, Nature Ecology \& Evolution, 2, 1588-1596, 10.1038/s41559-018-0662-8, 2018.

Chen, R., Senbayram, M., Blagodatsky, S., Myachina, O., Dittert, K., Lin, X., Blagodatskaya, E., and Kuzyakov, Y.: Soil C and N availability determine the priming effect: microbial $\mathrm{N}$ mining and stoichiometric decomposition theories, Global change biology, 20, 2356-

$5052367,2014$.

De Vries, F. T., Hoffland, E., van Eekeren, N., Brussaard, L., and Bloem, J.: Fungal/bacterial ratios in grasslands with contrasting nitrogen management, Soil Biology and Biochemistry, 38, 2092-2103, 2006. 
https://doi.org/10.5194/bg-2022-41

Preprint. Discussion started: 22 February 2022

(c) Author(s) 2022. CC BY 4.0 License.

Del Grosso, S., Parton, W., Stohlgren, T., Zheng, D., Bachelet, D., Prince, S., Hibbard, K., and Olson, R.: Global potential net primary production predicted from vegetation class, precipitation, and temperature, Ecology, 89, 2117-2126, 2008.

510 Delgado-Baquerizo, M., Maestre, F. T., Gallardo, A., Bowker, M. A., Wallenstein, M. D., Quero, J. L., Ochoa, V., Gozalo, B., GarcíaGómez, M., and Soliveres, S.: Decoupling of soil nutrient cycles as a function of aridity in global drylands, Nature, 502, 672, 2013.

Doetterl, S., Stevens, A., Six, J., Merckx, R., Van Oost, K., Pinto, M., Casanova-Katny, A., Munoz, C., Boudin, M., Venegas, E., and Boeckx, P.: Soil carbon storage controlled by interactions between geochemistry and climate, Nature Geoscience, 8, 780-+, 10.1038/NGEO2516, 2015.

515 Fick, S. E. and Hijmans, R. J.: Worldclim 2: New 1-km spatial resolution climate surfaces for global land areas., 2017.

Fierer, N. and Jackson, R. B.: The diversity and biogeography of soil bacterial communities, Proceedings of the National Academy of Sciences of the United States of America, 103, 626-631, 2006.

Franco, L. F. M. and Pessôa Filho, P. d. A.: On the solubility of proteins as a function of pH: Mathematical development and application, Fluid Phase Equilibria, 306, 242-250, https://doi.org/10.1016/j.fluid.2011.04.015, 2011.

520 Fuka, M. M., Engel, M., Gattinger, A., Bausenwein, U., Sommer, M., Munch, J. C., and Schloter, M.: Factors influencing variability of proteolytic genes and activities in arable soils, Soil biology and Biochemistry, 40, 1646-1653, 2008.

Gislason, S. R., Oelkers, E. H., Eiriksdottir, E. S., Kardjilov, M. I., Gisladottir, G., Sigfusson, B., Snorrason, A., Elefsen, S., Hardardottir, J., Torssander, P., and Oskarsson, N.: Direct evidence of the feedback between climate and weathering, Earth and Planetary Science Letters, 277, 213-222, 10.1016/j.eps1.2008.10.018, 2009.

525 Grayston, S. J., Griffith, G. S., Mawdsley, J. L., Campbell, C. D., and Bardgett, R. D.: Accounting for variability in soil microbial communities of temperate upland grassland ecosystems, Soil Biology and Biochemistry, 33, 533-551, https://doi.org/10.1016/S00380717(00)00194-2, 2001.

Gu, B., Schmitt, J., Chen, Z., Liang, L., and McCarthy, J. F.: Adsorption and desorption of natural organic matter on iron oxide: mechanisms and models, Environmental Science \& Technology, 28, 38-46, 1994.

530 Gu, B., Schmitt, J., Chen, Z., Liang, L., and McCarthy, J. F.: Adsorption and desorption of different organic matter fractions on iron oxide, Geochimica et Cosmochimica Acta, 59, 219-229, https://doi.org/10.1016/0016-7037(94)00282-Q, 1995.

Hendriksen, N. B., Creamer, R. E., Stone, D., and Winding, A.: Soil exo-enzyme activities across Europe-The influence of climate, landuse and soil properties, Applied Soil Ecology, 97, 44-48, https://doi.org/10.1016/j.apsoil.2015.08.012, 2016.

Hood-Nowotny, R., Umana, N. H.-N., Inselbacher, E., Oswald- Lachouani, P., and Wanek, W.: Alternative methods for measuring

535 inorganic, organic, and total dissolved nitrogen in soil, Soil Science Society of America Journal, 74, 1018, 10.2136/sssaj2009.0389, 2010.

$\mathrm{Hu}$, L. T. and Bentler, P. M.: Cutoff Criteria for Fit Indexes in Covariance Structure Analysis: Conventional Criteria Versus New Alternatives, Structural Equation Modeling-a Multidisciplinary Journal, 6, 1-55, 10.1080/10705519909540118, 1999.

Hu, Y., Zheng, Q., Zhang, S., Noll, L., and Wanek, W.: Significant release and microbial utilization of amino sugars and d-amino acid enantiomers from microbial cell wall decomposition in soils, Soil Biology and Biochemistry, 123, 115-125, 2018.

540 Jangid, K., Williams, M. A., Franzluebbers, A. J., Sanderlin, J. S., Reeves, J. H., Jenkins, M. B., Endale, D. M., Coleman, D. C., and Whitman, W. B.: Relative impacts of land-use, management intensity and fertilization upon soil microbial community structure in agricultural systems, Soil Biology and Biochemistry, 40, 2843-2853, 2008.

Jones, D. L., Owen, A. G., and Farrar, J. F.: Simple method to enable the high resolution determination of total free amino acids in soil solutions and soil extracts, Soil Biology and Biochemistry, 34, 1893-1902, 2002.

545 Kaiser, C., Koranda, M., Kitzler, B., Fuchslueger, L., Schnecker, J., Schweiger, P., Rasche, F., Zechmeister - Boltenstern, S., Sessitsch, A., and Richter, A.: Belowground carbon allocation by trees drives seasonal patterns of extracellular enzyme activities by altering microbial community composition in a beech forest soil, New Phytologist, 187, 843-858, 2010.

Kaiser, K. and Guggenberger, G.: The role of DOM sorption to mineral surfaces in the preservation of organic matter in soils, Organic Geochemistry, 31, 711-725, http://dx.doi.org/10.1016/S0146-6380(00)00046-2, 2000.

550 Kaiser, K. and Guggenberger, G.: Mineral surfaces and soil organic matter, European Journal of Soil Science, 54, 219-236, 10.1046/j.1365-2389.2003.00544.x, 2003.

Kang, H. Z., Xin, Z. J., Berg, B., Burgess, P. J., Liu, Q. L., Liu, Z. C., Li, Z. H., and Liu, C. J.: Global pattern of leaf litter nitrogen and phosphorus in woody plants, Annals of Forest Science, 67, 8, 10.1051/forest/2010047, 2010.

Khare, N., Eggleston, C. M., Lovelace, D. M., and Boese, S. W.: Structural and redox properties of mitochondrial cytochrome c co-sorbed

555 with phosphate on hematite ( $\alpha-\mathrm{Fe} 2 \mathrm{O} 3)$ surfaces, Journal of colloid and interface science, 303, 404-414, 2006.

Kim, S.: ppcor: Partial and Semi-Partial (Part) Correlation., https://CRAN.R-project.org/package=ppcor, 2015.

Kirkham, D. and Bartholomew, W.: Equations for following nutrient transformations in soil, utilizing tracer data, Soil Science Society of America Journal, 18, 33-34, 1954.

Kleber, M., Mikutta, R., Torn, M., and Jahn, R.: Poorly crystalline mineral phases protect organic matter in acid subsoil horizons,

560 European Journal of Soil Science, 56, 717-725, 2005.

Kögel - Knabner, I., Guggenberger, G., Kleber, M., Kandeler, E., Kalbitz, K., Scheu, S., Eusterhues, K., and Leinweber, P.: Organo mineral associations in temperate soils: Integrating biology, mineralogy, and organic matter chemistry, Journal of Plant Nutrition and Soil Science, 171, 61-82, 10.1002/jpln.200700048, 2008. 
https://doi.org/10.5194/bg-2022-41

Preprint. Discussion started: 22 February 2022

(c) Author(s) 2022. CC BY 4.0 License.

Koutsoukos, P. G., Norde, W., and Lyklema, J.: Protein adsorption on hematite ( $\alpha$-Fe2O3) surfaces, Journal of Colloid and Interface

565 Science, 95, 385-397, https://doi.org/10.1016/0021-9797(83)90198-4, 1983.

Kuo, S.: Phosphorus. p. 869-919. DL Sparks (ed.) Methods of soil analysis. Part 3. SSSA Book Ser. 5. SSSA, Madison, WI, Phosphorus. p. 869-919. In DL Sparks (ed.) Methods of soil analysis. Part 3. SSSA Book Ser. 5. SSSA, Madison, WI., -, 1996.

La Pierre, K. J., Blumenthal, D. M., Brown, C. S., Klein, J. A., and Smith, M. D.: Drivers of Variation in Aboveground Net Primary Productivity and Plant Community Composition Differ Across a Broad Precipitation Gradient, Ecosystems, 19, 521-533, 10.1007/s10021-

$570 \quad 015-9949-7,2016$.

Lachouani, P., Frank, A. H., and Wanek, W.: A suite of sensitive chemical methods to determine the delta15N of ammonium, nitrate and total dissolved N in soil extracts, Rapid Commun Mass Spectrom, 24, 3615-3623, 10.1002/rcm.4798, 2010.

Lajtha, K., Driscoll, C., Jarrell, W., and Elliott, E.: Soil phosphorus: characterization and total element analysis, Standard soil methods for long-term ecological research. Oxford University Press, New York, 115-142, 1999.

575 Lauber, C. L., Hamady, M., Knight, R., and Fierer, N.: Soil pH as a predictor of soil bacterial community structure at the continental scale: a pyrosequencing-based assessment, Applied and Environmental Microbiology, 2009.

Lauber, C. L., Strickland, M. S., Bradford, M. A., and Fierer, N.: The influence of soil properties on the structure of bacterial and fungal communities across land-use types, Soil Biology and Biochemistry, 40, 2407-2415, https://doi.org/10.1016/j.soilbio.2008.05.021, 2008.

Leinemann, T., Preusser, S., Mikutta, R., Kalbitz, K., Cerli, C., Höschen, C., Mueller, C. W., Kandeler, E., and Guggenberger, G.:

580 Multiple exchange processes on mineral surfaces control the transport of dissolved organic matter through soil profiles, Soil Biology and Biochemistry, 118, 79-90, https://doi.org/10.1016/j.soilbio.2017.12.006, 2018.

Loeppert, R. H.: Iron Methods of Soil Analysis. Part 3, in: Methods of Soil Analysis Part 3, edited by: Sparks, D. L., SSSA Book Series, Soil Science Society of America, Inc. \& American society of Agronomy, Inc., Madison, WI, 639-664, 1996.

Luo, Z., Feng, W., Luo, Y., Baldock, J., and Wang, E.: Soil organic carbon dynamics jointly controlled by climate, carbon inputs, soil

585 properties and soil carbon fractions - Luo - 2017 - Global Change Biology - Wiley Online Library, Global Change Biology, 23, 4430 4439, 10.1111/gcb.13767, 201.

Lützow, M. v., Kögel - Knabner, I., Ekschmitt, K., Matzner, E., Guggenberger, G., Marschner, B., and Flessa, H.: Stabilization of organic matter in temperate soils: mechanisms and their relevance under different soil conditions-a review, European Journal of Soil Science, 57 , 426-445, 2006.

590 Martens, D. A. and Loeffelmann, K. L.: Soil amino acid composition quantified by acid hydrolysis and anion chromatography-pulsed amperometry, Journal of Agricultural and Food Chemistry, 51, 6521-6529, 2003.

Marty, C., Houle, D., Gagnon, C., and Courchesne, F.: The relationships of soil total nitrogen concentrations, pools and C:N ratios with climate, vegetation types and nitrate deposition in temperate and boreal forests of eastern Canada, Catena, 152, 163-172, 10.1016/j.catena.2017.01.014, 2017.

595 Mikutta, R., Kaiser, K., Dörr, N., Vollmer, A., Chadwick, O. A., Chorover, J., Kramer, M. G., and Guggenberger, G.: Mineralogical impact on organic nitrogen across a long-term soil chronosequence (0.3-4100 kyr), Geochimica et Cosmochimica Acta, 74, 2142-2164, 2010 .

Mooshammer, M., Wanek, W., Schnecker, J., Wild, B., Leitner, S., Hofhansl, F., Blöchl, A., Hämmerle, I., Frank, A. H., and Fuchslueger, L.: Stoichiometric controls of nitrogen and phosphorus cycling in decomposing beech leaf litter, Ecology, 93, 770-782, 2012.

600 Nierop, K. G., Jansen, B., and Verstraten, J. M.: Dissolved organic matter, aluminium and iron interactions: precipitation induced by metal/carbon ratio, $\mathrm{pH}$ and competition, Science of the Total Environment, 300, 201-211, 2002.

Noll, L., Zhang, S., and Wanek, W.: Novel high-throughput approach to determine key processes of soil organic nitrogen cycling: Gross protein depolymerization and microbial amino acid uptake, Soil Biology and Biochemistry, 130, 73-81, https://doi.org/10.1016/j.soilbio.2018.12.005, 2019a.

605 Noll, L., Zhang, S., Zheng, Q., Hu, Y., and Wanek, W.: Wide-spread limitation of soil organic nitrogen transformations by substrate availability and not by extracellular enzyme content, Soil Biology and Biochemistry, 133, 37-49, https://doi.org/10.1016/j.soilbio.2019.02.016, 2019 b.

Peng, X. and Wang, W.: Stoichiometry of soil extracellular enzyme activity along a climatic transect in temperate grasslands of northern China, Soil Biology and Biochemistry, 98, 74-84, https://doi.org/10.1016/j.soilbio.2016.04.008, 2016.

610 Peter J Hernes, R. B., Gregory L Cowie, Miguel A Goñi, Brian A Bergamaschi, John I Hedges,: Tannin diagenesis in mangrove leaves from a tropical estuary: a novel molecular approach, Geochimica et Cosmochimica Acta, 65, 3109-3122, 2001.

Prommer, J., Wanek, W., Hofhansl, F., Trojan, D., Offre, P., Urich, T., Schleper, C., Sassmann, S., Kitzler, B., Soja, G., and HoodNowotny, R. C.: Biochar decelerates soil organic nitrogen cycling but stimulates soil nitrification in a temperate arable field trial, PLoS One, 9, e86388, 10.1371/journal.pone.0086388, 2014.

615 Pronk, G. J., Heister, K., and Kögel-Knabner, I.: Is turnover and development of organic matter controlled by mineral composition?, Soil Biology and Biochemistry, 67, 235-244, 2013.

Quiquampoix, H.: Mechanisms of protein adsorption on surfaces and consequences for extracellular enzyme activity in soil, in: Soil biochemistry, 171-206, 2000. 
https://doi.org/10.5194/bg-2022-41

Preprint. Discussion started: 22 February 2022

(c) Author(s) 2022. CC BY 4.0 License.

(c) (i)

Quiquampoix, H. and Ratcliffe, R. G.: A 31P NMR study of the adsorption of bovine serum albumin on montmorillonite using phosphate and the paramagnetic cation Mn2+: modification of conformation with $\mathrm{pH}$, Journal of Colloid and Interface Science, 148, 343-352, https://doi.org/10.1016/0021-9797(92)90173-J, 1992.

R Development Core Team: R: A language and environment for statistical computing, R Foundation for Statistical Computing [code], 2008.

Reich, P. B. and Oleksyn, J.: Global patterns of plant leaf N and P in relation to temperature and latitude, Proceedings of the National

625 Academy of Sciences of the United States of America, 101, 11001-11006, 10.1073/pnas.0403588101, 2004.

Rosseel, Y.: The lavaan tutorial, 2018.

Rousk, J., Bååth, E., Brookes, P. C., Lauber, C. L., Lozupone, C., Caporaso, J. G., Knight, R., and Fierer, N.: Soil bacterial and fungal communities across a $\mathrm{pH}$ gradient in an arable soil, The ISME journal, 4, 1340, 2010.

Scheel, T., Pritsch, K., Schloter, M., and Kalbitz, K.: Precipitation of enzymes and organic matter by aluminum-Impacts on carbon

630 mineralization, Journal of Plant Nutrition and Soil Science, 171, 900-907, 10.1002/jpln.200700146, 2008.

Schulten, H.-R. and Schnitzer, M.: The chemistry of soil organic nitrogen: a review, Biology and Fertility of Soils, 26, 1-15, 1997.

Sinsabaugh, R. L., Lauber, C. L., Weintraub, M. N., Ahmed, B., Allison, S. D., Crenshaw, C., Contosta, A. R., Cusack, D., Frey, S., Gallo, M. E., Gartner, T. B., Hobbie, S. E., Holland, K., Keeler, B. L., Powers, J. S., Stursova, M., Takacs - Vesbac, C., Waldrop, M. P., Wallenstein, M. D., Zak, D. R., and Zeglin, L. H.: Stoichiometry of soil enzyme activity at global scale, Ecology Letters, 11, 1252-1264, $63510.1111 / \mathrm{j} .1461-0248.2008 .01245 . x, 2008$.

Six, J. and Jastrow, J. D.: Organic matter turnover, Encyclopedia of soil science, 936-942, 2002.

Staunton, S. and Quiquampoix, H.: Adsorption and conformation of bovine serum albumin on montmorillonite: Modification of the balance between hydrophobic and electrostatic interactions by protein methylation and $\mathrm{pH}$ variation, Journal of Colloid and Interface Science, 166, 89-94, https://doi.org/10.1006/jcis.1994.1274, 1994.

640 Wanek, W., Mooshammer, M., Blöchl, A., Hanreich, A., and Richter, A.: Determination of gross rates of amino acid production and immobilization in decomposing leaf litter by a novel $15 \mathrm{~N}$ isotope pool dilution technique, Soil Biology and Biochemistry, 42, 1293-1302, 10.1016/j.soilbio.2010.04.001, 2010.

Wattel-Koekkoek, E. J. W., van Genuchten, P. P. L., Buurman, P., and van Lagen, B.: Amount and composition of clay-associated soil organic matter in a range of kaolinitic and smectitic soils, Geoderma, 99, 27-49, https://doi.org/10.1016/S0016-7061(00)00062-8, 2001.

645 Wild, B., Schnecker, J., Barta, J., Capek, P., Guggenberger, G., Hofhansl, F., Kaiser, C., Lashchinsky, N., Mikutta, R., Mooshammer, M., Santruckova, H., Shibistova, O., Urich, T., Zimov, S. A., and Richter, A.: Nitrogen dynamics in Turbic Cryosols from Siberia and Greenland, Soil Biol Biochem, 67, 85-93, 10.1016/j.soilbio.2013.08.004, 2013.

Yaalon, D. H.: Soils in the Mediterranean region: what makes them different?, CATENA, 28, 157-169, https://doi.org/10.1016/S03418162(96)00035-5, 1997.

650 Yang, Y., Fang, J., Ma, W., and Wang, W.: Relationship between variability in aboveground net primary production and precipitation in global grasslands, Geophysical Research Letters, 35, 2008.

Zhang, L. and Altabet, M. A.: Amino-group-specific natural abundance nitrogen isotope ratio analysis in amino acids, Rapid Commun Mass Spectrom, 22, 559-566, 10.1002/rcm.3393, 2008. 